\title{
Temperature increase affects acetate-derived methane production in Alaskan lake sediments and wetland soils
}

Dellagnezze, BM ${ }^{1}$, Bovio-Winkler ${ }^{1}$, P., Lavergne, C. ${ }^{2,3}$, Menoni, D.A ${ }^{1}$., Mosquillo, F. ${ }^{1}$, Cabrol, $\mathrm{L}^{3,4,5}$, Barret, M. ${ }^{6}$ Etchebehere, C. ${ }^{1}$

1. Microbial Ecology Laboratory, Department of Microbial Biochemistry and Genomic, Biological Research Institute “Clemente Estable," Montevideo, Uruguay

2. HUB AMBIENTAL UPLA, Laboratory of Aquatic Environmental Research, Centro de Estudios Avanzados, Universidad de Playa Ancha, Valparaíso, Chile

3. Escuela Ingeniería Bioquímica, Pontificia Universidad Católica de Valparaíso, Avenida Brasil 2085, Valparaíso, Chile

4. Aix-Marseille Université, Univ Toulon, CNRS, IRD - Mediterranean Institute of Oceanography (MIO, UM 110), 13288 Marseille, France.

5. Institute of Ecology and Biodiversity IEB, Faculty of Sciences, Universidad de Chile, Santiago, Chile

6. Laboratoire 'Ecologie Fonctionnelle et Environnement, Université de Toulouse, CNRS, Toulouse, France

* Correspondence to: Claudia Etchebehere

Microbial Ecology Laboratory, Department of Microbial Biochemistry and Genomics, Biological Research Institute “Clemente Estable”, Av. Italia 3318. CP 11600. Montevideo -Uruguay. 
Phone: (598) 24871616. Fax: (598) 24875461

cetchebehere@iibce.edu.uy

\section{Conflict of interest:}

Authors declare no conflict of interest.

Running title: Increasing temperature effect on methane production 


\begin{abstract}
Under climate change framework, methanogens activity is expected to be strongly affected, eventually resulting in positive feedback on global climate, with higher greenhouse gas (GHG) emissions in the Arctic. This work aimed to evaluate the effect of increasing temperature on methane production rate and archaeal community of lake sediments and wetland soils from Denali to Toolik regions in Alaska (USA). For that, anaerobic acetate-amended microcosms were incubated at $5,10,15$ and $20^{\circ} \mathrm{C}$. The acetate-derived methanogenic rate was determined and the methanogenic communities were analyzed by qPCR and 16S rRNA sequencing. Warmer temperatures yielded 4-6 times higher methane production rates and organic matter content (OM) showed significant positive correlation to methane production. Different patterns were observed in the archaeal communities after incubation at higher temperatures, with an increase in Methanosarcina abundance for most of the samples and Methanosaeta in one of the lakes tested, showing the adaptation of key acetoclastic groups among different temperatures. Our results demonstrate the impact of increasing temperature on methane production, bringing insights on key drivers involved in the process of acetoclastic methanogenic potential occurring in these ecosystems in Alaska.
\end{abstract}

Keywords: methane, freshwater ecosystems, climate change, 16S rRNA amplicons 


\section{INTRODUCTION}

Due to polar amplification, the Arctic has been regarded as one of the most susceptible regions to the effects of climate change. The Intergovernmental Panel for Climate Change (IPCC) report (Technical Summary 2019), points out changes in Northern Hemisphere since 1950 as decrease of snow cover, shrinking of glaciers and temperature increase of permafrost. These changes are also mentioned in another report, stating since the 1970s, Alaska has warmed around $2.5^{\circ} \mathrm{F}$ when compared to about $1.5^{\circ} \mathrm{F}$ for the whole United States (NOAA, 2019).

The Arctic concentrates almost $30 \%$ of permafrost, storing around $50 \%$ of worldwide organic carbon (Zhang et al., 2003; Chowdhury, 2015). Wetlands and freshwater ecosystems (lakes, ponds) in high latitude represent one of the largest sources of the greenhouse gas methane $\left(\mathrm{CH}_{4}\right)$, accounting for more than $40 \%$ of natural $\mathrm{CH}_{4}$ emissions (Rosentreter et al., 2021; Cui et al., 2015). Projections indicate that the Arctic is warming faster than tropical regions and may reach up to $9{ }^{\circ} \mathrm{C}$ of mean annual air temperature in the $22^{\text {th }}$ century (Collins et al., 2013; Wik et al., 2016). Such increase can lead to a positive feedback on $\mathrm{CH}_{4}$ production, due to accelerated thawing of permafrost enabling a major organic carbon degradation, causing longer ice-free conditions (Koven et al., 2001; Aronson et al, 2013; Basiliko et al., 2013; Cui et al., 2015; Wik et al., 2016, Wrona et al., 2015; Wen et al, 2017).

Methanogenic archaea can produce $\mathrm{CH}_{4}$ through different pathways from $\mathrm{H}_{2} / \mathrm{CO}_{2}$, methyl groups or acetate. Acetate is formed from decomposition of organic matter (OM) and is in the main $\mathrm{CH}_{4}$ precursor. The fate of acetate in a methanogenic environment is largely dependent on the physicochemical conditions, such as temperature, $\mathrm{pH}$ and salinity for example (Stams et al., 2019). In wetlands, thawed permafrost and low temperatures lakes sediments, acetate driven methanogenesis is considered to be the dominant pathway, while $\mathrm{H}_{2} / \mathrm{CO}_{2}$ pathways often occurs at acidic condition and mainly in deep layers (Coolen \& Orsi, 2015, Cui et al., 2015, Lyu et al., 2018, Kotsyurbenko et al., 2019, Lavergne et al., 2021). Whatever the pathway considered, the last step of this process is mediated by a single enzyme, the methyl-coenzyme $\mathrm{M}$ reductase (mcr), 
reported to be highly sensitive to temperature. The $\alpha$ subunit of this enzyme (mcrA) is considered as a molecular marker to characterize methanogenic communities (Steinberg \& Regan, 2009; He et al., 2015).

In Alaska, lake sediments and wetlands soils mainly from North Slope, like Utqiagvik (former Barrow and surroundings) and Arctic Foothills have been investigated regarding $\mathrm{CH}_{4}$ emission potential as well the microbial diversity involved. Lake sediments were reported regarding methane cycling using incubations (Bretz \& Whalen, 2014), temperature effect on production and methane natural emission/ incubation (Lofton et al., 2014; Matheus Carnevali et al., 2015; de Jong et al., 2018). Microbial diversity involved in methanogenesis from wetland soils were evaluated in microcosms (Wagner et al., 2017; Chowdhury et al., 2015; Yang et al., 2018). Apart from Toolik region (edge of Toolik lake, within North Slope region), the other ecosystems investigated here are situated in central Alaska, near Fairbanks.

The four lakes investigated here have been previously studied, regarding the in-situ measurement of $\mathrm{CH}_{4}$ emission fluxes (Walter Anthony \& Anthony, 2013, Greene et al., 2014; Sepulveda-Jauregui et al., 2015) and $\mathrm{CH}_{4}$ oxidation potential through incubations (Martinez-Cruz et al., 2015; He et al., 2015). Nonetheless, methanogenic communities involved in $\mathrm{CH}_{4}$ generation are scarcely reported and still unclear (Coolen \& Orsi, 2015). Thus, this work presents novel insights on acetate derived methanogenic potential and archaeal communities involved in this process under increasing temperatures in five lake sediments and wetland soils from Alaska.

We aimed to answer the following questions: $i)$ What are the effects of increasing temperature on acetoclastic methanogenic activity and archaeal community composition? ii) What are the differences of archaeal community structure among sampling sites in situ and after incubation? iii) Which factors affect the $\mathrm{CH}_{4}$ production rates? $\mathrm{iv}$ ) Is the abundance of $m c r A$ genes related with methanogenic activity? 


\section{MATERIAL AND METHODS}

\subsection{Sampling sites}

Lake sediments (L) and wetland soil (W) samples were collected during summer 2016 in five different locations in Alaska State, USA: Killarney Lake (L1 and W1), Otto Lake (L2), Nutella Lake (L3), Goldstream Lake (L4), and Toolik Lake (W2). For lake sediments, sampling was performed at the center of the lake at maximum depth in duplicate at some meter of distance. Sample site characteristics are summarized in Table 1.

Sediment samples collected using an Ekman dredge were placed in sterile plastic bottles (1L, Nalgene $\left.{ }^{\circledR}\right)$. Wetland soils were collected in 3 points and the sampling spots were divided in two subsamples, according to the depth: top (between 0-10 cm,) and bottom $(10-20 \mathrm{~cm})$. The average among replicates are presented aiming an overall characterization of each ecosystem (Table 2). Soil samples were collected in sterile plastic bags and placed in a cool container $\left(4^{\circ} \mathrm{C}\right)$ before being processed, subsequently subdivided for physicochemical and molecular analyses. Subsamples for anaerobic incubations were transferred into a sterile plastic bag under $\mathrm{N}_{2}$ flux and sealed.

\subsection{Physicochemical Analyses}

Physicochemical parameters such as temperature, $\mathrm{pH}$ or conductivity were determined for each collected sample, following protocols described in Lavergne et al., (2021). Replicates of sediment/wetland soil samples were dried overnight at $105^{\circ} \mathrm{C}$ to determine dry weight (DW) and then heated to $550{ }^{\circ} \mathrm{C}$ for approximately three hours in a muffle furnace in order to determine organic matter content (OM). Porewater was filtered from sediments according to Jones and Willett (2006) in order to determine anions and cations concentrations. For that, an aliquot of $40 \mathrm{~g}$ of sample was suspended in $200 \mathrm{~mL}$ deionized water using a magnetic stirrer at room temperature for $1 \mathrm{~h}$. Then, the liquid phase was filtered through a microRhizon sampler (Rhizosphere, 
Netherlands) and pH was measured (HI9829, Hanna). Ammonium, nitrite, nitrate and sulfate concentrations were determined through liquid chromatography (HPLC Dionex, USA) (Table 2).

\subsection{Microcosms set-up}

A total of four lake sediments (L1 to L4) and two wetland soils (W1 and W2, including subsampling points, top and bottom) were investigated regarding methane production. Microcosms were prepared under anaerobic conditions (Pyramid GloveBox, Captair, France) in sterile glass flasks $(12 \mathrm{~mL})$; four replicates per sample per temperature), sealed with rubber stoppers and aluminum crimp. An aliquot of $8 \mathrm{~g} \mathrm{OM} \mathrm{L}^{-1}$ of soil or sediment sample was added to each vial and the flasks were filled until $10 \mathrm{~mL}$ with mineral media (modified from Shelton \& Tiedje, 1984), amended with acetate $(30 \mathrm{mM})$, leaving $1 \mathrm{~mL}$ for headspace. The $\mathrm{pH}$ of mineral media was adjusted to the $\mathrm{pH}$ value of each sample measured in situ. All replicates were incubated in controlled temperature chambers at $5{ }^{\circ} \mathrm{C}, 10{ }^{\circ} \mathrm{C}, 15^{\circ} \mathrm{C}$ and $20{ }^{\circ} \mathrm{C}\left( \pm 1^{\circ} \mathrm{C}\right)$. After sealing, an equilibration period of 24 hours was applied, and then flasks were purged. The acetate consumption was checked at the end of the incubation through GC-FID (Adorno et al., 2014) (data not shown).

\subsection{Acetoclastic methanogenic activity}

Accumulated biogas was monitored by measuring the pressure in the microcosm headspace, with a manual manometer (Sper Scientific, USA, Portable Handheld Pressure Meter Wide Range, model 840065). Measurements were performed weekly or twice a week, depending on the activity of each sample. Gas chromatography (GC) was used to measure methane concentration in the headspace. An aliquot of $250 \mu \mathrm{L}$ of headspace was injected using $0.5 \mathrm{~mL}$ sample-lock syringe (Hamilton, model 1750SL, USA) into a gas chromatographer (SRI Instruments, model 310C; injector temperature $40{ }^{\circ} \mathrm{C}$, column temperature $150{ }^{\circ} \mathrm{C}$, detector temperature $40{ }^{\circ} \mathrm{C}$ ) equipped with a thermic conductivity detector (TCD) and Packed Column (6' X1/8" SRI Instruments, USA), using argon as carrier gas (99.9\% Linde, Uruguay). Calibration 
curves were performed periodically in gas-tight propylene bags (FlexFoil PLUS, USA) using pure methane gas $\left(\mathrm{CH}_{4}: 99.9 \%\right.$ Linde) and nitrogen $\left(\mathrm{N}_{2}: 100 \%\right.$, Linde gas) and methane standard was injected at each measurement series for accurate measurements. Results were exported from software Peak Simple (version 3.93). Accumulated methane in both gaseous and liquid phases was calculated using the ideal gas equation and Henry's law. Methane production rate (MPR) was calculated by linear regression, as the maximum slope of methane accumulation kinetics, following Lavergne et al. (2021). Methane production rates were normalized by the quantity of sample (calculated as dry weight- DW) in each incubation ( $\mu$ mol $\left.\mathrm{CH}_{4} \mathrm{~g}^{-1} \mathrm{DW} \mathrm{d}^{-1}\right)$. We considered the latency period as the time to reach $10 \%$ of maximum observed methane production rate.

$\mathrm{Q}_{10}$ coefficient was calculated according to Sepulveda-Jauregui et al (2018) to evaluate the influence of temperature on MPR. Calculation was made between $5{ }^{\circ} \mathrm{C}$ and $15{ }^{\circ} \mathrm{C}\left(\mathrm{Q} 10\left[5-15^{\circ} \mathrm{C}\right]\right)$ and $10{ }^{\circ} \mathrm{C}$ and $20{ }^{\circ} \mathrm{C}\left(\mathrm{Q}_{10}\left[10-20{ }^{\circ} \mathrm{C}\right]\right)$. Temperature dependence of methanogenesis was also estimated using activation energy (Ea) value, applying Arrhenius equation, as described in Lavergne et al. (2021) (Table 3).

\subsection{DNA extraction}

DNA was extracted from an aliquot of $0.25 \mathrm{~g}$ of all in situ samples (lake sediments and wetland soils) and samples collected after the methanogenic assays. Samples were centrifuged $\left(6000 \mathrm{rpm}, 30\right.$ minutes at $\left.4^{\circ} \mathrm{C}\right)$ at the end of the methanogenic activity (considered when no increased pressure was observed and kinetic curve reached a plateau). Power Soil Isolation kit (QIAGEN®, USA) was used following the instructor's guide. The final DNA concentration as well as DNA purity (ratio 260/280) were quantified using Nanodrop ${ }^{\circledR}$ (Thermo Scientific, USA).

\subsection{Abundance of targeted $m c r A$ and archaeal 16S rRNA genes by qPCR}

In order to quantify the archaeal 16 rRNA gene and the functional gene $\operatorname{mcr} A$ (indicative of methanogenesis), quantitative PCR (qPCR) was employed only for samples collected in situ. After 
optimization of qPCR conditions to avoid inhibition due to the sample template (data not shown), the reaction mix contained 0.4 or $1 \mu \mathrm{M}$ of each primer (see Supp. Table 1), $2 \mu \mathrm{L}$ of DNA template 10- or 100-fold diluted in ultrapure water (corresponding to $0.5-4 \mathrm{ng}$ sample DNA), $10 \mu \mathrm{L}$ of master mix (2X Takyon ROX SYBR master mix, Eurogentec, Belgium) and nuclease-free water to a final volume of $20 \mu \mathrm{L}$. All reactions were done in duplicate using AriaMX thermocycler (Agilent, USA) with Aria Software v1.3 (Agilent, USA). Standard curves and qPCR conditions are described in Supplementary material.

\subsection{Archaeal community composition determination by 16S rRNA gene sequencing}

Amplicon massive sequencing of the V3-V5 region of the 16S rRNA archaeal gene was performed using an Archaeal-specific primer set (340F 5'-CCCTAHGGGGYGCASCA-3' and 787R 5'- GGACTACVSGGGTATCTAAT -3') (Yu et al., 2005; Pinto et al., 2012). Only one representative sample was selected of each different incubation for sequencing. For wetland soils, only top layer samples were considered (W1T and W2T). Amplicons were checked on a 1\% agarose gel electrophoresis and then purified using a commercial kit (ZR Zymoclean ${ }^{\mathrm{TM}}$ Gel DNA Recovery Kit, USA). Sequencing of the 16S rRNA gene amplicon libraries was carried out by the Ion Torrent Personal Genome Machine (PGM) platform at the Biological Research Institute "Clemente Estable" (Montevideo, Uruguay).

\subsection{Bioinformatics analysis}

Sequence analysis was performed following the 'quantitative insights into microbial ecology’ pipeline (QIIME2 2019.10 release) (Bolyen et al., 2019). Multiplexed single-end sequencing reads $(3,916,062$ in total) were imported into the QIIME2.

The 'divisive amplicon denoising algorithm' DADA2 (Callahan et al., 2016) plugin in QIIME2 was used to filter out noise and correct errors in marginal sequences, remove chimeric sequences and singletons and dereplicate the sequences, resulting in high resolution amplicon 
sequence variants (ASVs). ASVs represent, as closely as possible, the original biological sequence of the sequenced amplicon.

Sequencing resulted in 790,220 sequences ranging from 976 to 72,831 per sample representing 1,289 ASVs (sequence length of $410 \mathrm{pb}$ ) and were classified with a classify-sklearn trained against the most recent SILVA 16S rRNA gene reference 138.1 database (Quast et al., 2012). Raw sequence data are available in the Sequence Read Archive (SRA) of NCBI under the BioProject PRJNA666194.

\subsection{Statistical Analyses}

All the statistical analysis was performed in R v3.5.1 (R Core Team, 2013) with R Studio environment (v1.3.1093). Because of non-normal distribution of the data (evaluated by ShapiroWilk's test), Spearman correlation tests were performed to verify the relationship between abundance of $m c r A$ genes or physicochemical parameters with MPR (methane production rate). Pearson correlation was applied to verify the effect of temperature on MPR and latency period. Significant differences and correlations were considered at $\mathrm{p}<0.05$.

In order to correlate physicochemical data with MPR, a multivariate principal component analysis (PCA) was carried out ('FactoMineR' package) (Husson et al., 2013). The PCA was built with 11 variables, including MPR at 5, 10, 15 and $20{ }^{\circ} \mathrm{C}$, environmental temperature and $\mathrm{pH}$ (measured in situ), dissolved organic carbon (DOC), organic matter (OM), electric conductivity and sulfate and nitrate + nitrite concentration.

One-way ANOVA was applied to verify significant differences among MPR at four different temperatures for all samples, as well as the depth for wetland soils. The effect of temperature on MPR and latency period (lag phase) were evaluated likewise.

Regarding diversity analyses, the biom file from QIIME2 was imported and analyzed through phyloseq-modified workflow (McMurdie and Holmes, 2013). Alpha diversity in each sample was calculated based on the number of observed ASVs using Shannon diversity index after 
rarefying, normalized with 976 sequences per samples (Shannon, 1948; Simpson, 1949). Taxon relative abundance bar charts were generated using custom $\mathrm{R}$ scripts and ggplot2 (v3.3.2). Heatmap of the relative abundance of ASVs (represented at phylum and genus level) was generated using ampvis2 (v.2.6.5) (Andersen et al., 2018). Venn diagram (http://bioinformatics.psb.ugent.be/webtools/Venn/) was used to determine the shared ASVs among samples at the lowest and highest temperature in microcosms $\left(5^{\circ} \mathrm{C}\right.$ and $\left.20{ }^{\circ} \mathrm{C}\right)$. For Venn diagram construction we only considered 183 ASVs with a relative abundance above $1 \%$ of archaeal community.

Permutational analysis of variance (PERMANOVA) was applied in order to analyze the influence of ecosystem and the effect of temperature incubation on the archaeal diversity distribution, (adonis function, 'vegan' package; Oksanen et al., 2013). These analyses were run in two conditions: i) incubated + in situ samples; ii) only incubated samples at four different temperatures. Principal coordinate analysis (PCoA) was used to evaluate the distribution of samples only in natural condition (in situ). PCoA using Bray Curtis distance metrics of nontransformed relative abundance table was computed with phyloseq and plotted using ggplot2.

\section{RESULTS}

\subsection{Methane production rate (MPR) in incubated lake sediments and wetland soils}

Methane production was monitored along time in the incubations at the different temperatures.

Temperature influenced significantly MPR and latency periods in all lake sediments and wetland top samples. Pearson correlation showed strong correlation between temperature and MPR, as temperature and latency period ( $p<0.05, \rho>0.9)$. All lake sediment samples incubated at warmer temperatures $\left(15^{\circ} \mathrm{C}\right.$ and $20^{\circ} \mathrm{C}$ showed significant higher MPR $(\mathrm{p}<0.05)$ and longer latency periods $(\mathrm{p}<0.05)$ when compared to the coldest temperatures $\left(5^{\circ} \mathrm{C}\right)$ (Fig. 1A and $\left.1 \mathrm{~B}\right)$. 
The rate of acetate-driven methane production from lake sediment samples was higher at $20^{\circ} \mathrm{C}$ and varied from $3.8 \pm 0.03$ (Killarney Lake) to 5.6 $\pm 0.6 \mu$ moles $\mathrm{CH}_{4} \mathrm{~g}^{-1} \mathrm{DW} \mathrm{d}^{-1}$ (Otto Lake) (Fig. 1). At $5^{\circ} \mathrm{C}, \mathrm{MPR}$ were on average 5 times lower than at $20^{\circ} \mathrm{C}$, ranging from $0.54 \pm 0.05$ (Killarney Lake) to $1.15 \pm 0.2 \mu$ moles $\mathrm{CH}_{4} \mathrm{~g}^{-1} \mathrm{DW} \mathrm{d} \mathrm{d}^{-1}$ (Nutella Lake). Despite significant differences of MPRs among four temperatures $\left(5\right.$ to $20^{\circ} \mathrm{C}$ ), when compared among the four lake sediments (L1-L4) no significant differences were found ( $p$ > 0.05) (Fig 1A).

As lake sediments, temperature had significative and strong positive correlation with MPRs $(\mathrm{p}<0.05, \rho>0.9)$ in all wetland soil samples, exceptionally to Toolik B. Pearson correlation between temperature and latency periods was statistically significant and strongly negative $(\mathrm{p}<$ $0.05, \rho>-0.9$ ) only for top samples (W1T, W2T). MPRs were higher at $15{ }^{\circ} \mathrm{C}$ and $20{ }^{\circ} \mathrm{C}$ than at $5^{\circ} \mathrm{C}(\mathrm{p}<0.05)$, which at $20^{\circ} \mathrm{C} \mathrm{MPR}$ increased about 4-5 times ranging from $4.21 \pm 0.4$ (Killarney - W1B) to $29.12 \pm 0.7$ (Toolik W2B) $\mu$ moles $\mathrm{CH}_{4} \mathrm{~g}^{-1} \mathrm{DW} \mathrm{d}{ }^{-1}$. At $5^{\circ} \mathrm{C}$, methane production was not detected for the bottom layer of the Toolik (W2 B) and the highest MPR were observed at Toolik T $\left(5.7 \pm 1.8 \mu\right.$ moles $\mathrm{CH}_{4} \mathrm{~g}^{-1} \mathrm{DW} \mathrm{d} \mathrm{d}^{-1}$. Comparing both ecosystems, MPRs showed no significant differences $(\mathrm{p}>0.05)$ between Killarney and Toolik soils. Nonetheless, depth had significative influence on MPR only in Killarney wetland soil (W1 T $\neq$ W1 B) (Fig. 1A). Latency periods pronouncedly diverged in top layer samples ( $<<0.05$, W1T and W2T), which Killarney (W1 T) presented shorter latency period, $\left(10\right.$ days at $20^{\circ} \mathrm{C}$ to 68 at $\left.5{ }^{\circ} \mathrm{C}\right)$ than samples from Toolik (W2 T) with 45 days at $20^{\circ} \mathrm{C}$ to 146 at $5^{\circ} \mathrm{C}$ ) (Fig. 2A).

For all samples, the $\mathrm{Q}_{10}$ indicated that an increase by $10^{\circ} \mathrm{C}$ had a positive impact on methanogenic production (in average $5 \pm 2.2$ for $\mathrm{Q}_{10}\left[5-15^{\circ} \mathrm{C}\right]$ and $2 \pm 0.5$ for $\mathrm{Q}_{10}\left[10-20^{\circ} \mathrm{C}\right]$ (Table 3). It is worthy to note that an increase of $10^{\circ} \mathrm{C}$ had a major effect in the lowest temperature range $\left(5\right.$ to $15^{\circ} \mathrm{C}$ ) compared to the highest range ( $\mathrm{t}$-test, $\mathrm{t}=4.42, \mathrm{p}<0.05$ ). Moreover, the overall temperature dependence of methanogenesis evaluated by the energy activation (Ea) showed similar values for lake sediment samples (mean: $81.9 \pm 11.4 \mathrm{~kJ} \mathrm{~mol}^{-1}$, corresponding to $0.84 \pm 0.15$ 
$\mathrm{eV}$ ) and wetland soil (mean: $56.3 \pm 26.8 \mathrm{~kJ} \mathrm{~mol}^{-1}$, corresponding to $0.58 \pm 0.27 \mathrm{eV}$ ) (Table 3 ). The highest values was displayed by the Otto Lake, reaching up to $98.7 \mathrm{~kJ} \mathrm{~mol}^{-1}(1.02 \mathrm{eV})$.

\subsection{Physicochemical analysis and effects on methane production}

Values of several physicochemical parameters measured in the samples are presented in Table 2. The highest dissolved organic carbon (DOC) contents were observed in Killarney lake sediment samples $\left(21.81 \mathrm{mg} \mathrm{L}^{-1}\right)$ and Killarney soil bottom samples (21.01 $\left.\mathrm{mg} \mathrm{L}^{-1}\right)$. Also, Killarney top (W1 T) presented the highest concentration of nitrate + nitrite $\left(0.133 \mathrm{mg} \mathrm{L}^{-1}\right)$. Regarding organic matter content (OM), the highest values were observed in the samples from Goldstream and Nutella Lakes, 0.179 and $0.172 \mathrm{~g} \mathrm{OM} \mathrm{g}^{-1} \mathrm{DW}$, respectively and Toolik bottom (W2 B), $0.716 \mathrm{~g} \mathrm{OM} \mathrm{g}^{-1}$ DW. Otto lake sample presented the highest content of sulfate (12.36 mg $\left.\mathrm{L}^{-1}\right)$.

To elucidate which physicochemical factors was related to the MPRs, principal component analysis (PCA) was applied to 11 variables. The two first dimensions of the PCA built with MPRs at the four tested temperatures $\left(5,10,15\right.$ and $\left.20^{\circ} \mathrm{C}\right)$, in situ temperature, conductivity, $\mathrm{pH}$, dissolved organic carbon (DOC), sulfate, nitrate + nitrite concentrations and OM represented $60.21 \%$ of the total dataset variation (Table 2, Fig. 2A). OM concentration was significantly correlated to MPR in all samples at 10,15 and $20^{\circ} \mathrm{C}$ (Spearman correlation, $\rho>0.6$, p-value $<0.05$ ). Moreover, based on the two first dimensions of the PCA, samples were significantly clustered according to their biome, with a clear distinction between tundra (Toolik soil and Nutella Lake) and boreal forest (Killarney, Goldstream) (PERMANOVA, F = 4.18, p-value < 0.05) (Fig. 2B). 


\subsection{S rRNA archaeal and mcrA gene abundance in sediment lake and wetland soils}

In all in-situ samples, both archaeal communities and methanogens were detected (Fig. 3). Among lake sediments, the highest archaeal 16S rRNA gene copy number was observed for samples from Goldstream lake (L4) $\left(1.05 \times 10^{9} \pm 2.72 \times 10^{7}\right.$ copies $\left.\mathrm{g}^{-1} \mathrm{DW}\right)$ and the lowest value was observed in Killarney lake (L1) $\left(4.51 \times 10^{7} \pm 2.51 \times 10^{6}\right.$ copies $\left.\mathrm{g}^{-1} \mathrm{DW}\right)$. For wetland soils, the highest and lowest values of archaeal 16S rRNA gene copy number were observed respectively in bottom samples from Toolik (W2 B) $\left(2.07 \times 10^{9} \pm 3.96 \times 10^{6}\right.$ copies $\left.\mathrm{g}^{-1} \mathrm{DW}\right)$ and Killarney (W1 B) $\left(6.14 \times 10^{7} \pm 3.17 \times 10^{6}\right.$ copies $\left.\mathrm{g}^{-1} \mathrm{DW}\right)$.

The highest abundance of functional gene $m c r A$ was found in Nutella Lake samples (L3) (2.81 x $10^{8}$ copies $\mathrm{g}^{-1} \mathrm{DW}$, with $51 \%$ of $m c r A$ in total Archaea) and Goldstream Lake samples (L4) (2.96 $\times 10^{8}$ copies $\mathrm{g}^{-1} \mathrm{DW}, 28 \%$ of $m c r A$ in total Archaea). Likewise, among wetland soils, the highest $m c r A$ abundances were observed in Toolik bottom soil samples (W2 B) $\left(8.59 \times 10^{9}\right.$ copies $\mathrm{g}^{-1} \mathrm{DW}, 41 \%$ of $m c r A$ in total Archaea), followed by top soil samples from Killarney (W1 T) (1.15 x $10^{8}$ copies $\mathrm{g}^{-1} \mathrm{DW}, 33 \%$ of $m c r A$ in total Archaea). No significant correlations were found between mcrA gene abundances and MPRs independently of the considered temperature (Spearman correlations, $\rho=-0.08-0.03$, $p$-value $>0.05$ ).

\subsection{Methanogenic community analysis}

Archaeal communities were largely dominated by the phylum Halobacterota $(36.1 \%$ of total Archaea) in all incubated samples at all temperatures, and in most in-situ samples, followed by phyla Crenarcheota, Euryarcheota, Thermoplasmatota and Nanoarcheota (Fig. 5A). The characterization at the genus level, revealed the presence of known methanogens, representing $26 \%$ of the total community .

In in situ samples, Methanosaeta was the most abundant genus in all lake sediment samples (ranging from 45 to $60 \%$, representing $6.2 \%$ of the total Archaea) while Methanoregula was found 
above $10 \%$ only in Nutella and Goldstream Lakes samples (25 and 14\%, respectively). Methanosarcina showed very low abundance in Killarney, Otto and Nutella Lake (1.8 to 4.5\%) and was not detected in Goldstream Lake. Bathyarchaeia class ranged around 10\% in all lakes. From wetland soils, archaeal diversity was assessed from the active layer (upper layer, 0-10 cm). In in-situ Killarney soils, Methanobacterium was found as the most abundant (50.8\%), followed by Methanosarcina (31.2\%). The in-situ community from Toolik soil (W2 T) showed the highest diversity (Shannon index, 3.66) (Supp. Fig. S4), dominated by Bathyarchaeia class (31\% of the total community), followed by Rice Cluster II family (11.3\%) and Methanosarcina (9.7\%). Woesearchaeales $(8.2 \%)$ and Nitrososphareaceae $(8.4 \%)$ were detected more abundantly in this sample (Supp. Fig. S1).

Alpha diversity analysis (Shannon index) showed a decline after microcosm incubations in all samples, being significative lower at 5, 10 and $20^{\circ} \mathrm{C}(\mathrm{p}<0.05)$, mainly in Toolik soil (Supp. Fig. S4). Indeed, Methanosarcina was globally predominant in microcosms (60-99\% of archaeal relative abundance), at all temperatures, in all samples, except for the samples from Goldstream Lake, where the genus Methanosaeta prevailed at all temperatures (49-67\% of relative abundance). Methanosaeta was found at $15^{\circ} \mathrm{C}$ incubation in Otto lake (44.7\%) and Toolik peat (52.7\%) (Supp. Fig. S1). The effect of different temperatures on diversity (Shannon index) was not significant in any sample (Spearman correlation, $\mathrm{p}>0.05, \rho<0.4$ ). DNA extraction from samples of Otto Lake and Toolik soils for sequencing were extracted later than others, which could have infer in this variance.

The most abundant genera found in microcosms were Methanosarcina (represented by 97 ASVs) or Methanosaeta (53 ASVs). Despite being affiliated to the same genus, the most part of ASVs were observed as site-specific, exceptionally some occurring in Otto lake, punctually in determined temperature (Supp. Fig. S2). Venn diagram was constructed to evaluate the shared ASVs between samples taken in situ and after incubation, at the lowest $\left(5^{\circ} \mathrm{C}\right)$ and highest $\left(20^{\circ} \mathrm{C}\right)$ temperatures. 
In wetland soils, only 2 ASVs (both related to Methanosarcina) were shared between in situ and incubated samples (at $5^{\circ} \mathrm{C}$ and $20^{\circ} \mathrm{C}$ ), $10 \mathrm{ASVs}$ (where 5 related to Methanosaeta, 4 to Methanosarcina and one to Methanoregula) were shared in lake sediments (Supp. Fig. S3), showing that the incubation induced a stronger divergence from natural conditions. A total of 10 and 16 ASVs mainly related to Methanosarcina genus were shared between samples incubated at 5 and $20^{\circ} \mathrm{C}$ for wetland soils and lakes sediments, respectively, mainly affiliated to Methanosarcina (Supp. Table S2). This result suggests that these methanogens, key acetoclastic groups (mostly Methanosarcina and Methanosaeta) could adapt to higher temperature $\left(20^{\circ} \mathrm{C}\right)$, in a psychrophilic/psychrotolerant range.

PCoA and PERMANOVA based on all ASVs revealed that samples primarily clustered according to the ecosystem type (wetland soils and sediment lakes), when considering all conditions evaluated; in situ + incubation at different temperatures, incubated samples only (Bray Curtis distance-based PCoA, PERMANOVA, p < 0.05, (Fig. 6A \& C). As a general rule, the in situ samples were clearly separated from the incubated ones, except for the Goldstream lake (L4) samples exhibiting a very stable archaeal composition in situ and after incubation (whatever the temperature) (Fig. 6A). Under natural conditions (in situ), lake sediments samples displayed similar archaeal community structure, with a clear cluster while wetland soils highly diverged between each other, reflecting the strongly different ecosystems between Toolik (tundra) and Killarney (boreal forest) (Fig. 6B). 


\section{DISCUSSION}

\subsection{Effects of increasing temperature and other environmental factors on $\mathrm{CH}_{4}$ production}

Higher temperatures $\left(15\right.$ and $\left.20^{\circ} \mathrm{C}\right)$ reduced latency period and strongly affected MPRs resulting in a 4-6-fold increase of acetate-based MPR when compared to the lowest ones (5 and $10{ }^{\circ} \mathrm{C}$ ). It is well defined that temperature is a limiting factor, defining metabolic functions and our results corroborates with other works performed in Arctic environment using incubation experiments (Hoj et al., 2008; Lofton et al., 2015; Blake et al., 2015, Herndon et al., 2015).

The $\mathrm{Q}_{10}$ coefficient represents the change of a rate in $10{ }^{\circ} \mathrm{C}$. According to Bennett (1990) and applied in Fuchs et al. (2016), Q 10 values between 0.2 and 0.8 can be considered as negative correlation, at $0.8-1.5$ not impacted by temperature and as positive correlation is stated values at $>1.5$. Also, $\mathrm{Q}_{10}$ values showed positive correlation at the lowest temperature range $\left(5-15{ }^{\circ} \mathrm{C}\right)$, mainly for Otto and Goldstream Lakes $\left(\mathrm{Q}_{10}>6\right)$, showing strong temperature sensitivity, suggesting more energy input to methanogenesis than in the other ecosystems evaluated. These values can be comparable to those found in acetoclastic incubation experiments at low temperatures (de Jong et al., 2018, Blake et al., 2015). However, $Q_{10}$ values were slightly lower than observed in SepulvedaJauregui et al. (2018), a study involving both lakes without substrate addition and tested in a broader temperature range. The overall methanogenesis dependence to temperature (Ea) was on average $0.84 \pm 0.15 \mathrm{eV}$ in lake sediments. This value fits within the universal Ea range defined by Yvon-Durocher et al. (2014) $(0.82-1.27 \mathrm{eV})$ and also corresponds to similar values recently published by Lavergne et al. (2021) using the same protocol in sub-Antarctic lake sediments.

As mentioned previously, ecosystems investigated here were studied by SepulvedaJauregui and collaborators (2015) through field measurements of $\mathrm{CH}_{4}$ emission associated with biogeographical and physicochemical features. They verified lakes Nutella and Otto as non- 
yedoma type peatlands, emitting lower $\mathrm{CH}_{4}$ amounts than Goldstream and Killarney classified as yedoma type peatlands. Despite diverging in natural conditions, in controlled anoxic microcosms all samples reached around $5 \mu$ moles of $\mathrm{CH}_{4} \mathrm{~g}^{-1} \mathrm{DW} \mathrm{d}^{-1}$ at $20^{\circ} \mathrm{C}$. Considering the methanogenesis stimulation by $30 \mathrm{mM}$ of acetate and the temperatures tested, the MPRs were lower than other reported in lake sediments from Alaska. From the North Slope region (Alaska), microcosm amended with $2 \mathrm{mM}$ of acetate at 4 and $10{ }^{\circ} \mathrm{C}$, presented a higher MPR of $4.7 \mu$ moles $\mathrm{CH}_{4} \mathrm{~g}^{-1} \mathrm{DW}$ $\mathrm{d}^{-1}$ at $10^{\circ} \mathrm{C}$ (de Jong et al., 2018). In non-amended incubation, sediment lake samples from Barrow surroundings yielded a rate of $2.2 \mu$ moles $\mathrm{CH}_{4} \mathrm{~g}^{-1} \mathrm{DW} \mathrm{d}^{-1}$ at $10{ }^{\circ} \mathrm{C}$ (Matheus Carnevali et al., 2015), similar to our results, despite no substrate addition. Our MPRs are also almost 3-times lower than the rates found in a similar study of sub-Antarctic lake sediments stimulating $\mathrm{CH}_{4}$ production with $30 \mathrm{mM}$ of acetate within the same temperature range (Lavergne et al., 2021).

MPRs were in average 3 times higher in wetland soil samples than lake sediments. Although not significant differences observed ( $p>0.05$ ), between two wetland ecosystems, Toolik samples yielded higher MPR than Killarney, with higher MPR in Toolik soil bottom (W2 B; 10$20 \mathrm{~cm}$ depth). These samples were collected from Tundra region, and presented the highest OM content among all samples evaluated, with strong correlation with MPR $(\rho>0.8)$. Shaver et al. (2013) reported soils ecosystems in Toolik Lake region, stating these soils typically have high OM content overlying a poorly developed mineral soil. Thus, along with temperature, substrate availability is crucial for $\mathrm{CH}_{4}$ cycle in natural systems. Some works performed in different locations of the Arctic report that organic rich soils can yield higher amounts of $\mathrm{CH}_{4}$ than mineral soils; Alaska (Chowdhury et al., 2015), Siberia (Ganzert et al., 2006), Norway (Høj et al., 2008). Depth is a factor linked to the moisture and temperature of soil, influencing the turnover of soil OM (Kechavarzi et al., 2010). $\mathrm{CH}_{4}$ accumulation at increased temperatures can be higher in deep layers than in surface; however, this can vary depending on the soil type (Wang et al., 2017). 


\subsection{Methanogens abundance and MPRs}

The MPR values do not accurately correlate with mcrA gene abundances. While previous works have shown that mcrA gene could be a good molecular marker for methanogenesis (Lavergne et al 2021, Zhang et al., 2019, Yang et al., 2018), we found no significant correlation between mcrA gene abundance (in situ samples) and MPRs, which is in line with Freitag and Prosser (2009). Moreover, qPCR was carried out based on DNA approach, which provide us a "general" information and potential, but not the functionally active genes during incubation period. Franchi et al., (2018) evaluated $m c r A$ gene in anaerobic digestion process under both approaches (DNA and RNA), observing in spite of high abundance, low gene expression was observed and no correlation with methane production was found as well.

Despite no positive correlation, the highest abundances of $m c r A$ were observed in the samples taken from Goldstream Lake (L4) and Toolik soils (“bottom”- W2 B), also presenting the highest MPR. However, the detection of $m c r A$ genes and the MPR obtained even at $5^{\circ} \mathrm{C}$ could have indicated the potential of methanogenesis in the ecosystems sampled.

\subsection{Methanogenic microbial communities' composition}

The community composition was more influenced by ecosystem type than by temperature of incubation. When PCoA was performed using all the 16S rRNA genes sequences datasets, a separation of the samples according to the ecosystem and not according to the temperature of incubation was observed. The same separation was observed when the PCoA was performed using only the samples taken after incubation. These results indicate that methanogenic communities were particularly influenced by ecosystem type. In addition, similar patterns where other factors than temperature influence diversity were observed in wetland samples from California, USA (He et al., 2015), from lake sediment in Germany (Glissman et al., 2002), in Chinese Zoige wetland (Tibetan plateau) (Cui at al., 2015). 
The communities from the samples taken in situ presented different composition according to the ecosystem type. The communities from the lakes were dominated by Methanosaeta genus (Methanosarcinales) (from 45.8 to $60.9 \%$ relative abundance), followed by Methanoregula and Methanobacterium genera. The samples taken from wetlands exhibited different methanogenic communities, with a dominance of Methanosarcina and Methanobacterium in Killarney wetland soil (W1) and a dominance of Bathyarchaeia and Rice cluster II in Toolik soil (W2). Our findings corroborate with other works performed in Arctic environment. Methanosarcinales, Methanomicrobiales, Methanobacterales orders have been reported in high abundance in response to the permafrost thaw in Tibetan Plateau and in Chinese wetland (Wei et al., 2018; Cui et al., 2015), palsa peatland in Norway (Liebner et al., 2015), and permafrost thaw ponds in Canada (Crevecoeur et al., 2016). In Alaska, Methanosarcinales, Methanomicrobiales were found as active members in upper layer of sediment lakes from near Barrow, North Slope (Matheus Carnevali et al., 2018) and in thawed active layer from Hess Creek (Mackelprang et al., 2011). At genus level, Methanoregula was found as the most abundant in sediment lake samples and Methanosarcina and Methanobacterium accounted for more than $90 \%$ of all classified archaeal methanogens in wetland ecosystems in the Canadian Arctic (Stoeva et al. 2013; Frank-Fahle et al., 2014). In Alaska, Methanobacterium and Methanosarcina significantly correlated with the methane production at various depth levels in tundra and boreal forest soils cores (Tripathi et al. 2017).

The groups of archaea mostly present in Toolik samples was also previously observed in samples from cold environments. Rice cluster II lineage have been described as dominant phylotype in thawing permafrost in Sweden (Mondav et al., 2014) and boreal peatlands in Finland (Juottonen et al., 2015). Toolik soil harbored most Bathyarchaeia members (Crenarcheota/Bathyarcheota phylum) and almost exclusively ASVs related to the recently classified Woesearchaeales order and Nitrososphaeraceae. Bathyarchaeia is a wide group, associated with anoxic environments, like termite gut (Loh et al., 2020), deep seafloor (Chen et al, 
2020) and freshwater (Fillol et al., 2015). Their physiology is associated with several functions as acetogenesis and methane metabolism (Zhoug et al., 2018). Woesearchaeales (phylum Nanoarcheota, superphylum DPANN) are also reported with anaerobic metabolism in deep marine sediments, for example (Carrier et al., 2020). Woesearchaeales and Bathyarchaeia were described in thermokarst lakes in Alaska (Matheus Carnevali et al., 2018), in lake sediments from south Chile (Lavergne et al., 2021) and tundra permafrost soil in Alaska (Tripathi et al., 2019). Nitrososphaeraceae family members were related to ammonia oxidation, have been detected in tundra soil in Russia (Hetz \& Horn, 2021) and isolated from peatland in Norway (Candidatus Nitrosocosmicus arcticus) (Alves et al., 2018). Then, most of the groups detected in our work were previously found in cold environments suggesting their adaptation to low temperatures.

After microcosms incubation, the diversity decreased and two different patterns were observed: in most samples, a shift was observed with an increase in abundance of Methanosarcina, while in the samples taken from Goldstream lake, the in-situ dominant Methanosaeta persisted and was even enriched after incubation.

In the samples from lakes Killarney (L1), Otto (L2) and Nutella (L3), similar patterns were observed each other, Methanosaeta prevailed in the samples taken in situ and Methanosarcina predominated after incubation. In natural environment, low concentration of acetate and low temperatures may favor the obligate-acetoclastic Methanosaeta, which is more competitive than Methanosarcina under these conditions (Stam et al.,2019; Kotsyurbenko et al. 2019). Thus, despite the previous high abundance of Methanosaeta in situ, the generalist feature of Methanosarcina to use a broad range of substrates, producing methane through distinct metabolic pathways, may explain their dominance. Moreover, compared to Methanosaeta, Methanosarcina can better tolerate high acetate concentration (Stam, et al., 2019), which could have influenced their predominance in these in acetate amended microcosm.

The samples from Goldstream Lake presented a different behavior, with high abundance of Methanosaeta before and after incubation. A reasonable explanation for Methanosaeta 
prevalence exclusively in Goldstream Lake might be associated with the very low abundance of Methanosarcina (not detected) in natural samples (in situ). Also, Methanosaeta might be metabolically active in environmental condition; once active in situ, associated to very low abundance of Methanosarcina, may have led it to surpass and thrive on other members.

Acetoclastic pathway was reported to be the most likely process in thawing permafrost and one of the most important methanogenic substrates in low temperature environments (Frank- Fahle et al., 2014, Mackelprang et al., 2011, Coolen \& Orsi, 2015). Our results corroborate with other works performed through acetate incubation. Methanosaetaceae family was found as the most abundant in sediment lakes from Alaska with low concentration $(2 \mathrm{mM})$, at $10{ }^{\circ} \mathrm{C}$ (de Jong et al. 2018). From lake sediments in Norway, Blake et al. (2015) observed this shift where Methanosaetaceae was the most abundant before incubation, decreasing at $5^{\circ} \mathrm{C}$ and Methanosarcinaceae and Methanosaetaceae compounded major part of the community at $30^{\circ} \mathrm{C}$. On the other hand, our results contrast with a study in Canadian High Arctic permafrost where Methanococcales and Methanomicrobiales were found in acetoclastic incubations $(30 \mathrm{mM}$ as in our study) at $4{ }^{\circ} \mathrm{C}$ and $22{ }^{\circ} \mathrm{C}$ (Supplementary Table S2).

The samples from the two wetland sites presented higher diversity and in particular, the sample taken from Toolik was very diverse presenting high abundance of "not classified" sequences, or classified as uncultured microorganisms, suggesting this environment can harbor many unknown archaeal microorganisms so far. After incubation at four different temperatures, the pattern was similar to most of the other samples, with an enrichment of Methanosarcina.

One of the limitations of this work was that only acetoclastic methanogenic capacity was studied, then, we cannot infer from these results the response of the whole methanogens to temperature increase. In sub-Antarctic lake sediments, Lavergne et al. (2021) stimulated methanogenesis separately by acetate $(30 \mathrm{mM})$ and $\mathrm{H}_{2} / \mathrm{CO}_{2}(80 / 20 ; 1$ bar $)$ and showed that increasing temperatures (from 5 to $20{ }^{\circ} \mathrm{C}$ ) may increase the proportion of $\mathrm{CH}_{4}$ produced by hydrogenotrophs. Hence highlighting the necessity to better understand the effect of warming on 
the different methanogenic pathways and communities. Moreover, the results obtained could have been affected by the artificial concentration of acetate used in the experiments as discussed before. Then, further work is necessary to investigate the response to temperature in real conditions. Our results showed that members of Methanosarcina and Methanosaeta can outcompete other genera at all temperatures, showing an adaptation to both high and low temperatures. As discussed, these genera are widely reported inhabiting cold environments, in this psychrotolerant range $\left(5-20^{\circ} \mathrm{C}\right)$. Considering natural temperatures (in situ) measured from each ecosystem, our results showed the capacity of methanogens to cope with worse warming predictions; with the concomitant effect of increasing the $\mathrm{CH}_{4}$ production and the greenhouse effect associated with $\mathrm{CH}_{4}$.

\section{CONCLUSION}

Alaska American state as the Arctic region is considered a susceptible spot to be drastically changed in response to the current global warming phenomenon. The present work consisted in evaluating acetoclastic methanogenic potential from several lake and wetland soil ecosystems (not reported regarding archaeal diversity so far) at increasing temperature, through acetate amended incubations. The results corroborate with current works that increasing temperature has a direct influence and can boost the $\mathrm{CH}_{4}$ production in natural environments. In the archaeal communities, different patterns were observed after incubation to higher temperatures, with an increase in Methanosarcina abundance for most of the samples (lake sediments and wetland soils) and a persistence of Methanosaeta in one of the lakes tested, showing the adaptation of key acetoclastic groups to different temperatures. Besides temperature, organic matter content showed significant correlation with the methanogenic activity.

Archaeal methanogenic diversity reports are scarce in these environments. The present study brings new insights on methanogens from these environments and those involved in acetoclastic methane production in a broader location (center to north) in Alaska, gathering four 
lakes (Killarney, Otto, Nutella, Goldstream) and two wetland soil (Killarney and Toolik). Our work revealed diverse composition from the studied sites, with strong implications in different biogeochemical processes. Furthermore, the high abundance of Archaea classified as "uncultured" or "not classified" claims for further investigation in order to explore new phyla. The roles and metabolic interaction in metacommunities at increasing temperatures remains not fully elucidated in these underexplored environments, giving a cue to further work on methanogens groups inhabiting these areas. The data gathered here will complement previous works performed in these environments in Alaska (Sepulveda-Jauregui et al., 2015, Cruz et al., 2017) in order to better understand the complex process of $\mathrm{CH}_{4}$ cycle in climate change scenario in Alaska.

\section{REFERENCES}

Adorno, M.A.T., et al. (2014) Development and Validation of Two Methods to Quantify Volatile Acids (C2-C6) by GC/FID: Headspace (Automatic and Manual) and Liquid-Liquid Extraction (LLE). American Journal of Analytical Chemistry, 5, 406-414. http://dx.doi.org/10.4236/ajac.2014.57049.

Allan, J., Ronholm, J., Mykytczuk, N.C.S., Greer, C. W., Onstott, T. C., and Whyte L.G (2014) Methanogen community composition and rates of methane consumption in Canadian High Arctic permafrost soils. Environmental Microbiology Reports (2014) 6(2), 136-144. doi:10.1111/1758-2229.12139

Altshuler, I., Goordial, J., Whyte, L.G. (2017) Microbial Life in Permafrost (Chapter 8). In: R. Margesin (ed.), Psychrophiles: From Biodiversity to Biotechnology, Springer International Publishing AG. doi: 10.1007/978-3-319-57057-0_8

Alves R.J.E, Kerou M., Zappe A, Bittner R, Abby SS, Schmidt HA, Pfeifer K and Schleper C (2019) Ammonia oxidation by the arctic terrestrial Thaumarchaeote candidatus Nitrosocosmicus arcticus is stimulated by increasing temperatures. Front. Microbiol. 10:1571. doi: 10.3389/fmicb.2019.01571

Andersen K.S., Kirkegaard R.H., Karst S.M., Albertsen M. (2018) ampvis2: an R package to analyse and visualise 16S rRNA amplicon data. bioRxiv. doi: https://doi.org/10.1101/299537 
Aronson, E.L., Allison, S.D., and Helliker, B.R (2013) Environmental impacts on the diversity of methane-cycling microbes and their resultant function. Frontiers in Microbiology, Volume 4, Article 225. doi: 10.3389/fmicb.2013.00225

Basiliko , N., Henry, K., Gupta,V., Moore,T.R., Driscoll, B.T., and Dunfield, P.F. (2013) Controls on bacterial and archaeal community structure and greenhouse gas production in natural, mined, and restored Canadian peatlands. Frontiers in Microbiology, doi: 10.3389/fmicb.2013.00215

Barbier, B.A., Dziduch, I., Liebner, S., Ganzert, L., Lantuit, H., Pollard, W., Wagner, D. (2012) Methane-cycling communities in a permafrost-affected soil on Herschel Island, Western Canadian Arctic: active layer profiling of $m c r A$ and $p m o A$ genes. FEMS Microbiol Ecol 82, $287-$ 302.doi: 10.1111/j.1574-6941.2012.01332.x

Bennett, A. F. (1990), Thermal dependence of locomotor capacity, Am. J. Physiol.: Regul., Integr. Comp. Physiol., 259, R253-R258

Blake, L.I., Tveit, A., Øvreås, L., Head, I.M., and Gray, N.D. (2015) Response of Methanogens in Arctic Sediments to Temperature and Methanogenic Substrate Availability. PLoS ONE 10(6): e01. doi:10.1371/journal.pone.0129733

Blaud, A., Lerch, T.Z., Phoenix, G.K., and Osborn, A.M. (2015) Arctic soil microbial diversity in a changing world. Research in Microbiology, 1e 18. http://dx.doi.org/10.1016/j.resmic.2015.07.013

Bolyen E, Rideout JR, Dillon MR, Bokulich NA, Abnet CC, Al-Ghalith GA, Alexander H, Alm EJ, Arumugam M, Asnicar F, Bai Y, Bisanz JE, Bittinger K, Brejnrod A, Brislawn CJ, Brown CT, Callahan BJ, Caraballo-Rodríguez AM, Chase J, Cope EK, Da Silva R, Diener C, Dorrestein PC, Douglas GM, Durall DM, Duvallet C, Edwardson CF, Ernst M, Estaki M, Fouquier J, Gauglitz JM, Gibbons SM, Gibson DL, Gonzalez A, Gorlick K, Guo J, Hillmann B, Holmes S, Holste H, Huttenhower C, Huttley GA, Janssen S, Jarmusch AK, Jiang L, Kaehler BD, Kang KB, Keefe CR, Keim P, Kelley ST, Knights D, Koester I, Kosciolek T, Kreps J, Langille MGI, Lee J, Ley R, Liu YX, Loftfield E, Lozupone C, Maher M, Marotz C, Martin BD, McDonald D, McIver LJ, Melnik AV, Metcalf JL, Morgan SC, Morton JT, Naimey AT, Navas-Molina JA, Nothias LF, Orchanian SB, Pearson T, Peoples SL, Petras D, Preuss ML, Pruesse E, Rasmussen LB, Rivers A, Robeson MS 2nd, Rosenthal P, Segata N, Shaffer M, Shiffer A, Sinha R, Song SJ, Spear JR, Swafford AD, Thompson LR, Torres PJ, Trinh P, Tripathi A, Turnbaugh PJ, Ul-Hasan S, van der Hooft JJJ, Vargas F, Vázquez-Baeza Y, Vogtmann E, von Hippel M, Walters W, Wan Y, Wang M, Warren J, Weber KC, Williamson CHD, Willis AD, Xu ZZ, Zaneveld JR, Zhang Y, Zhu Q, Knight R, Caporaso JG (2019). Reproducible, interactive, scalable and extensible microbiome data science 
using QIIME 2. Nat Biotechnol.Aug;37(8):852-857. doi: 10.1038/s41587-019-0209-9. Erratum in: Nat Biotechnol. Sep;37(9):1091. PMID: 31341288; PMCID: PMC7015180.

Bretz, K.A., Whalen, S.C. (2014) Methane cycling dynamics in sediments of Alaskan Arctic Foothill lakes. Inland Waters 4, pp. 65-78, DOI: 10.5268/IW-4.1.637

Callahan, B., McMurdie, P., Rosen, M. et al. DADA2: High-resolution sample inference from Illumina amplicon data. Nat Methods 13, 581-583 (2016) doi:10.1038/nmeth.3869

Carrier, V., Svenning, M.M., Gründger, F., Niemann, H., Dessandier P-A, Panieri G., Kalenitchenko D.(2020) The Impact of Methane on Microbial Communities at Marine Arctic Gas Hydrate Bearing Sediment. Front. Microbiol. 11:1932. doi: 10.3389/fmicb.2020.01932

Chao, A., 1984. Nonparametric estimation of the number of classes in a population.Scand. J. Stat. 11, 265-270.

Chen Y., Mi., T., Liu, Y., Li, S.Zhen, Y. (2020) Microbial Community Composition and Function in Sediments from the Pearl River Mouth Basin. J. Ocean Univ. China (Oceanic and Coastal Sea Research), ISSN 1672-5182, 19 (4): 941-953. https://doi.org/10.1007/s11802-0204225-7

Chowdhury, TR., Herndon, EM, Phelps, TJ., Elias, DA, Gu, B., Liang, L., Wullschleger, SD., Graham, D.E (2015) Stoichiometry and temperature sensitivity of methanogenesis and CO2 production from saturated polygonal tundra in Barrow, Alaska. Global Change Biology (2015) 21, 722-737. doi: 10.1111/gcb.12762

Collins, M., Knutti, R., Arblaster, J., Dufresne, J.-L., Fichefet, T., Friedlingstein, P., Gao, X. Gutowski, W.J., Johns, T., Krinner, G., Shongwe, M., Tebaldi, C., Weaver, A.J., Wehner, M. (2013) Long-term Climate Change: Projections, Commitments and Irreversibility. In: Climate Change 2013: The Physical Science Basis. Contribution of Working Group I to the Fifth Assessment Report of the Intergovernmental Panel on Climate Change [Stocker, T.F., D. Qin, G.K. Plattner, M. Tignor, S.K. Allen, J. Boschung, A. Nauels, Y. Xia, V. Bex and P.M. Midgley (eds.)]. Cambridge University Press, Cambridge, United Kingdom and New York, NY, USA.

Coolen, MJL., Orsi WD (2015) The transcriptional response of microbial communities in thawing Alaskan permafrost soils. Front. Microbiol.6:197. doi: 10.3389/fmicb.2015.00197

Cui, M, Ma, A., Qi, H., Zhuang, X., Zhuang,G., and Zhao, G. (2015) Warmer temperature accelerates methane emissions from the Zoige wetland on the Tibetan Plateau without changing methanogenic community composition. Scientific Reports, 5:11616. doi: 10.1038/srep11616

Dong, X.Z., Chen, Z.J. Psychrotolerant methanogenic archaea: Diversity and cold adaptation mechanisms. Sci China Life Sci, 2012, 55: 415-421. doi: 10.1007/s11427-012-4320-0 
Einen, J., Thorseth, I.H., Øvreås, L. (2008) Enumeration of Archaea and Bacteria in seafloor basalt using real-time quantitative PCR and fluorescence microscopy, FEMS Microbiology Letters, Volume 282, Issue 2, Pages 182-187. https://doi.org/10.1111/j.1574-6968.2008.01119.x

Fillol, M., Alexandre Sanchez-Melsiò, A., Gich, F., Borrego, C.M. (2015) Diversity of Miscellaneous Crenarchaeotic Group archaea in freshwater karstic lakes and their segregation between planktonic and sediment habitats. FEMS Microbiology Ecology, 91, 2015, fiv020. doi: 10.1093/femsec/fiv020

Franchi, O., Bovio, P., Martínez, E.O., Rosenkranz, F., Chamy, R. (2018) Active and total microbial community dynamics and the role of functional genes bamA and $m c r A$ during anaerobic digestion of phenol and p-cresol. Bioresource Technology 264, 290-297. https://doi.org/10.1016/j.biortech.2018.05.060

Frank-Fahle, B.A, Yergeau, E., Greer, C.W., Lantuit, H., and Wagner, D. (2014) Microbial Functional Potential and Community Composition in Permafrost-Affected Soils of the NW Canadian Arctic. PLoS ONE 9(1): e84761. doi:10.1371/journal.pone.0084761

Freitag, TE., Prosser, J.I (2009) Correlation of Methane Production and Functional Gene Transcriptional Activity in a Peat Soil. Applied and Environmental Microbiology, Nov. 2009, p. 6679-6687 Vol. 75, No. 21, doi:10.1128/AEM.01021-09

Ganzert, L., Jurgens, G., Munster, U., Wagner, D. (2007) Methanogenic communities in permafrost-affected soils of the Laptev Sea coast, Siberian Arctic, characterized by 16 S rRNA gene fingerprints. FEMS Microbiol Ecol 59, 476-488. doi:10.1111/j.1574-6941.2006.00205.x

Glissmann, K., Chin, J., Casper, P., Conrad, R. (2004) Methanogenic Pathway and Archaeal Community Structure in the Sediment of Eutrophic Lake Dagow: Effect of Temperature Microbial Ecology, Vol. 48, No. 3, pp. 389-399. doi: 10.1007/s00248-003-2027-2

Greene, S., Walter Anthony, K.M., Archer, D., Sepulveda-Jauregui, A., and Martinez-Cruz, K. (2014) Modeling the impediment of methane ebullition bubbles by seasonal lake ice. Biogeosciences, 11, 6791-6811. doi:10.5194/bg-11-6791-2014

He, S., Malfatti, S.A, McFarland, J.W, Anderson, F.E., Pati, A., Huntemann, M., Tremblay, J., Glavina del Rio, T., Waldrop, M.P., Windham-Myers, L., Tringe, S.G. (2015) Patterns in wetland microbial community composition and functional gene repertoire associated with methane emissions. mBio 6(3):e00066-15. doi:10.1128/mBio.00066-15.

Herndon, E.M., Mann, B.F., Chowdhury, T.R., Yang, Z., Wullschleger, SD., Graham, D., Liang, L. and Gu, B (2015) Pathways of anaerobic organic matter decomposition in tundra soils from Barrow, Alaska, J. Geophys. Res. Biogeosci., 120, 2345-2359, doi:10.1002/ 2015JG003147. 
Hetz SA, Horn, M.A (2021) Burkholderiaceae are key acetate assimilators during complete denitrification in acidic cryoturbated peat circles of the arctic tundra. Front. Microbiol. 2:628269. doi: 10.3389/fmicb.2021.628269

Høj, L., Olsen, R.A.,Torsvik, V.L (2008) Effects of temperature on the diversity and community structure of known methanogenic groups and other archaea in high Arctic peat. The ISME Journal, 2, 37-48. doi:10.1038/ismej.2007.84

de Jong, A.E.E., et al. (2018) Increases in temperature and nutrient availability positively affect methane-cycling microorganisms in Arctic thermokarst lake sediments. Environmental Microbiology, doi:10.1111/1462-2920.14345

Kechavarzi, C., Dawson, Q., Bartlett, M., and Leeds-Harrison, P.B. (2010) The role of soil moisture, temperature and nutrient amendment on $\mathrm{CO} 2$ efflux from agricultural peat soil microcosms. Geoderma 154, 203-210. doi:10.1016/j.geoderma.2009.02.018

Jones, DL., Willet, V.B. (2006) Experimental evaluation of methods to quantify dissolved organic nitrogen (DON) and dissolved organic carbon (DOC) in soil. Soil Biology \& Biochemistry 38 (2006) 991-999. doi:10.1016/j.soilbio.2005.08.012

Juottonen, H., Kotiaho, M., Robinson, D., Merila, P, Fritze, H., Eeva-Stiina Tuittila, E.S. (2015) Microform-related community patterns of methane-cycling microbes in boreal Sphagnum bogs are site specific. FEMS Microbiology Ecology, 91, fiv094. doi: 10.1093/femsec/fiv094

Kotsyurbenko, O.R., Glagolev, M.V, Merkel, A.Y., Sabrekov, A.F, and Terentieva, I. E. (2019) Methanogenesis in soils, wetlands, and peat. Springer Nature Switzerland AG 2019 A. J. M. Stams, D. Z. Sousa (eds.), Biogenesis of Hydrocarbons, Handbook of Hydrocarbon and Lipid Microbiology, https://doi.org/10.1007/978-3-319-53114-4_9-1

Koven, C.D., Ringeval, B., Friedlingstein, P., Ciais, P., Cadule, P., Khvorostyanov, D., Krinner, G., and Tarnocai, C. (2011) Permafrost carbon-climate feedbacks accelerate global warming. PNAS, September, vol. 108, no. 36, 14769-14774 doi:10.1073/pnas.1103910108

Lavergne, C., Aguilar-Munoz, P., Calle, N., Thalasso, F., Astorga-Espana, M.S., Armando Sepulveda-Jauregui, A., Martinez-Cruz, K., Gandois, L., Mansilla, A., Chamy, R., Barret, M., Cabrol, L. (2021) Temperature differently affected methanogenic pathways and microbial communities in sub-Antarctic freshwater ecosystems. Environment International 154 (2021) 106575. https://doi.org/10.1016/j.envint.2021.106575

Liebner, S., Ganzert, L., Kiss A., Yang S., Wagner D., Svenning M.M. (2015) Shifts in methanogenic community composition and methane fluxes along the degradation of discontinuous permafrost. Front. Microbiol.6:356. doi:10.3389/fmicb.2015.00356 
Lofton, D.D., Whalen, S.C., Hershey, A.E. (2015) Vertical sediment distribution of methanogenic pathways in two shallow Arctic Alaskan lakes. Polar Biol., doi10.1007/s00300014-1641-4

Loh, HQ., Hervé, V., Brune, A. (2020) Metabolic potential for reductive acetogenesis and a novel energy-converting [ $\mathrm{NiFe}]$ hydrogenase in Bathyarchaeia from termite guts - a genomecentric analysis. bioRxiv preprint doi: https://doi.org/10.1101/2020.12.10.419648

Lyu, Z., Shao, N.,Akinyemi, T., Whitman, WB (2018) Methanogenesis. Current Biology 28, July 9, R719-R736

Mackelprang, R. et al. (2011) Metagenomic analysis of a permafrost microbial community reveals a rapid response to thaw. Nature, v.480, doi:10.1038/nature10576

Martinez-Cruz, K., A. Sepulveda-Jauregui, A., Anthony, KW, Thalasso, F. (2015) Geographic and seasonal variation of dissolved methane and aerobic methane oxidation in Alaskan lakes. Biogeosciences, 12, 4595-4606. doi:10.5194/bg-12-4595-2015

Matheus Carnevali, P. B., Rohrssen, M., Williams, M. R., Michaud, A. B., Adams, H., Berisford, D., Love, G. D., Priscu, J.C., Rassuchine, O., Hand, K. P., Murray, A. E. (2015) Methane sources in arctic thermokarst lake sediments on the North Slope of Alaska. Geobiology, doi: 10.1111/gbi.12124

Matheus Carnevali, P.B., Herbold, C.W., Hand, K.P., Priscu, J.C., Murray, A.E. (2018) Distinct microbial assemblage structure and archaeal diversity in sediments of arctic thermokarst lakes differing in methane sources. Front. Microbiol. 9:1192. doi: 10.3389/fmicb.2018.01192

Meredith, M., Sommerkorn, M., Cassotta, S., Derksen, C., Ekaykin, A., Hollowed, A., Kofinas, G., Mackintosh, A., Melbourne-Thomas, J., Muelbert, M.M.C., Ottersen, G., Pritchard, H., Schuur, E.A.G. (2019) Polar Regions. In: IPCC Special Report on the Ocean and Cryosphere in a Changing Climate [H.-O. Pörtner, D.C. Roberts, V. Masson-Delmotte, P. Zhai, M. Tignor, E. Poloczanska, K. Mintenbeck, A. Alegría, M. Nicolai, A. Okem, J. Petzold, B. Rama, N.M. Weyer (eds.)]. In press.

McMurdie, P. J., \& Holmes, S. (2013). phyloseq: an R package for reproducible interactive analysis and graphics of microbiome census data. PloS one, 8(4), e61217. https://doi.org/10.1371/journal.pone.0061217

Mondav, R., Woodcroft, B. J. et al. (2014) Discovery of a novel methanogen prevalent in thawing permafrost. Nat. Commun. 5:3212 doi: 10.1038/ncomms4212

Morris, R.L., Tale, V.P., Mathai, P.P., Zitomer, D.H., and Maki, J.S. (2015) mcrA gene abundance correlates with hydrogenotrophic methane production rates in full-scale anaerobic waste treatment systems. Letters in Applied Microbiology 62, 111-118. doi:10.1111/lam.12515 
NOAA National Centers for Environmental Information | State Climate Summaries, 2019 (www.ncei.noaa.gov | https://statesummaries.ncics.org/ak)

Pinto, A. J., and Raskin, L. (2012). PCR biases distort bacterial and archaeal community structure in pyrosequencing datasets. PLoS One 7. doi:10.1371/journal.pone.0043093.

Quast, C. et al. (2013) The SILVA ribosomal RNA gene database project: improved data processing and web-based tools, Nucleic Acids Research, Volume 41, Issue D1, 1, Pages D590D596. https://doi.org/10.1093/nar/gks1219

R Core Team, 2017: R Core Team (2017). R: A Language and Environment For Statistical Computing. St. Vienna: R Core Team.

Rosentreter, J.A., Borges, A.V., Deemer, B.R., Meredith A. Holgerson, M.A., Liu, S., Song, C., Melack, J., Raymond, P.A., Duarte, C.M., Allen, G.H., Olefeldt, D., Poulter, B., Battin, T.I., Eyre, B.D. (2021) Half of global methane emissions come from highly variable aquatic ecosystem sources Nature Geoscience, v.14, 225-230. https://doi.org/10.1038/s41561-021-00715-2

Sepulveda-Jauregui A., Walter Anthony, K. M., Martinez-Cruz, K., Greene, S., Thalasso, F. (2015) Methane and carbon dioxide emissions from 40 lakes along a north-south latitudinal transect in Alaska. Biogeosciences, 12, 3197-3223. doi:10.5194/bg-12-3197-2015

Sepulveda-Jauregui, A., Hoyos-Santillan, J., Martinez-Cruz, K., Walter Anthony, K.M., Casper, P., Belmonte-Izquierdo, Y., Thalasso, F. (2018) Eutrophication exacerbates the impact of climate warming on lake methane emission. Science of the Total Environment 636, 411-419. https://doi.org/10.1016/j.scitotenv.2018.04.283

Shannon, C.E. (1948) A mathematical theory of communication. Bell System Technical Journal, 27, 379- 423.

Shelton, D.R, Tiedje, J.M (1984) General method for determining anaerobic biodegradation potential. Applied And Environmental Microbiology, Vol.47,No.4,p.850-857

Simpson, E. H. (1949). Measurement of diversity.Nature,163, 688.

Stams, A.J.M, Teusink, B., Sousa, D.Z. (2019). Ecophysiology of Acetoclastic Methanogens. In book: Biogenesis of Hydrocarbons, Handbook of Hydrocarbon and Lipid Microbiology. Springer Nature Switzerland AG. https://doi.org/10.1007/978-3-319-53114-4_21-1

Steinberg, L.M, Regan, J.M. (2009) Phylogenetic comparison of the methanogenic communities from an acidic, oligotrophic fen and an anaerobic digester treating municipal wastewater sludge. Applied and Environmental Microbiology, p. 6663-6671, v. 74, no. 21. doi:10.1128/AEM.02858-08

Stoeva, M.K., Aris-Brosou, S., Chetelat, J., Hintelmann, H., Pelletier, P., et al. (2014) Microbial Community Structure in Lake and Wetland Sediments from a High Arctic Polar Desert 
Revealed by Targeted Transcriptomics. PLoS ONE 9(3): e89531. doi:10.1371/journal.pone.0089531

Tripathi, B.M. et al. (2017) Variations in bacterial and archaeal communities along depth profiles of Alaskan soil cores. Nature Scientific Reports 8:504, doi:10.1038/s41598-017-18777-x

Tripathi, B.M., Kim, H.M., Jung, J.Y., Nam, S., Ju, H.T., Kim, M., Lee, Y.K. (2019) Distinct Taxonomic and Functional Profiles of the Microbiome Associated With Different Soil Horizons of a Moist Tussock Tundra in Alaska. Front. Microbiol. 10:1442. doi: 10.3389/fmicb.2019.01442

Vanwonterghen, I et al. (2016) Methylotrophic methanogenesis discovered in the archaeal phylum Verstraetearchaeota. Article Number: 16170. doi: 10.1038/NMICROBIOL.2016.170

Yu, Y., Lee, C., Kim, J., \& Hwang, S. (2005). Group-specific primer and probe sets to detect methanogenic communities using quantitative real-time polymerase chain reaction. Biotechnology and bioengineering, 89(6), 670-679. doi: 10.1002/bit.20347

Yvon-Durocher, G., Allen, A.P, Bastviken, D, Conrad, R, Gudasz,C., St-Pierre, A, Duc, NT, Giorgio, PA (2014) Methane fluxes show consistent temperature dependence across microbial to ecosystem scales. Nature, v. 507, 27. doi:10.1038/nature13164

Walter Anthony, K.M., and Peter Anthony, P. (2013) Constraining spatial variability of methane ebullition seeps in thermokarst lakes using point process models. Journal of Geophysical Research: Biogeosciences, 118, 1015-1034. doi:10.1002/jgrg.20087

Wagner, R., Zona, D., Oechel W., Lipson D. (2017) Microbial community structure and soil pH correspond to methane production in Arctic Alaska soils. Envir. Microbiol., 19(8), 3398-3410. doi:10.1111/1462-2920.13854

Wang, X., Siciliano, S., Helgason, B., Bedard-Haughn, A. (2017) Responses of a mountain peatland to increasing temperature: A microcosm study of greenhouse gas emissions and microbial community dynamics. Soil Biology \& Biochemistry 110, $22 \mathrm{e} 33$. http://dx.doi.org/10.1016/j.soilbio.2017.02.013

Wei, S., Cui, H., Zhu, Y., Lu, Z., Pang, S., Zhang, S., Dong, H., Su, X. (2018) Shifts of methanogenic communities in response to permafrost thaw results in rising methane emissions and soil property changes. Extremophiles https://doi.org/10.1007/s00792-018-1007-x

Wen, X., Yang, S., Horn, F., Winkel, M., Wagner, D. and Liebner, S. (2017) Global Biogeographic Analysis of Methanogenic Archaea Identifies Community-Shaping Environmental Factors of Natural Environments. Front. Microbiol. 8:1339. doi: 10.3389/fmicb.2017.01339

Wickham, 2017: Wickham, H. (2017). ggplot2 - Elegant Graphics for Data Analysis. New York, NY: Springer, doi: 10.1007/978-0-387-98141-3 
Wik, M .et al (2016) Review: Climate-sensitive northern lakes and ponds are critical components of methane release. Nature Geoscience, doi: 10.1038/NGEO2578

Wrona, F.J., Johansson, M., Culp, J.M., Jenkins, A., Mård, J., Myers-Smith, I. H., Prowse, T.D., Vincent, W.F and Wookey, P.A. (2016) Transitions in Arctic ecosystems: Ecological implications of a changing hydrological regime, J. Geophys. Res. Biogeosci., 121, 650-674, doi:10.1002/2015JG003133.

Xu, X., Elias, D.A, Graham, D.E., Phelps, T.J., Carroll, S.L. Wullschleger, S.D.and Thornton, E. (2015) A microbial functional group-based module for simulating methane production and consumption: Application to an incubated permafrost soil, J. Geophys. Res. Biogeosci., 120, 1315-1333, doi:10.1002/2015JG002935.

Yang, Z., Yang, S., Van Nostrand, JD., Zhou, J., Fang, W., Qi, Q., Liu, Y., Wullschleger, SD., Liang, L. Graham, D.E, Yang, Y., Gu, B. (2018) Microbial Community and Functional Gene Changes in Arctic Tundra Soils in a Microcosm Warming Experiment. Front. Microbiol. 8:1741. doi: 10.3389/fmicb.2017.01741

Zhang, T., R.G. Barry, K. Knowles, F. Ling, and R.L. Armstrong (2003) Distribution of seasonally and perennially frozen ground in the Northern Hemisphere. In book: Permafrost, Phillips, Springman \& Arenson (eds), Swets \& Zeitlinger, Lisse, ISBN 9058095827.

Zhang,Y., Ma, A., Zhuang, G., Zhuang, X. (2019) The acetotrophic pathway dominates methane production in Zoige alpine wetland coexisting with hydrogenotrophic pathway. Scientific Reports, 9:9141. https://doi.org/10.1038/s41598-019-45590-5

Zhou, Z., Pan, J., Wang, F., Ji-Dong Gu, JD., Li, M. (2020) Bathyarchaeota: globally distributed metabolic generalists in anoxic environments. FEMS Microbiology Reviews, fuy023, 42, 2018, 639-655. doi: 10.1093/femsre/fuy023 

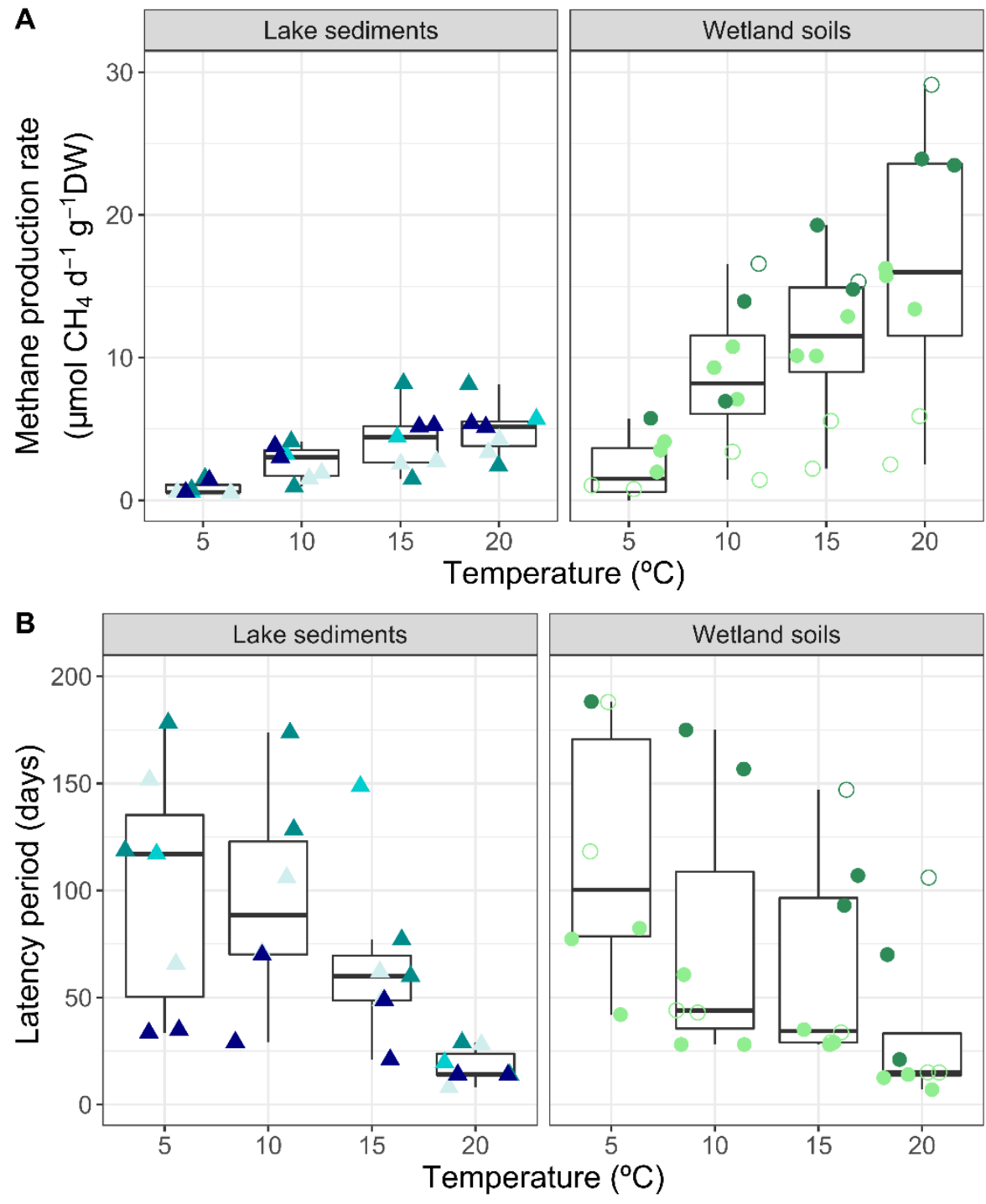
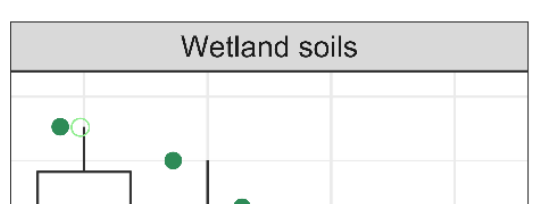

I
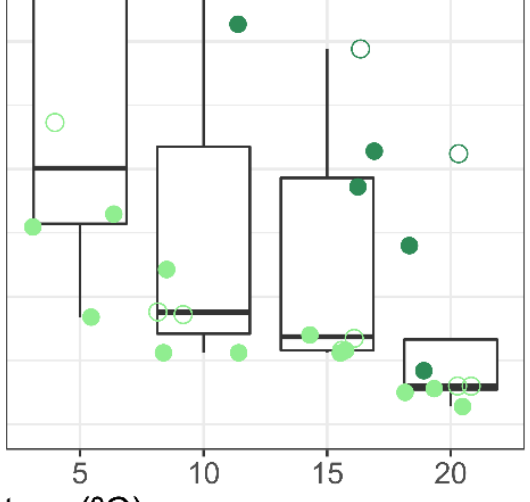

\section{Ecosystem}

Killarney (L1)

- Otto (L2)

- Nutella (L3)

- Goldstream (L4)

Killarney (W1)

- Toolik (W2)

\section{Type}

A Lake sediments

- Wetland soils - T

O Wetland soils - B

Figure 1. Boxplot representing the influence of temperature on both $\mathrm{CH}_{4}$ production rates (panel A) and latency periods (panel B) in acetate-amended microcosms from lake sediments and wetland soils. Type of freshwater systems was plotted by different shapes and the 6 ecosystems were represented by colors. For wetland soils, distinction was made between top (T) (disks) and bottom (B) (open circles) samples. 

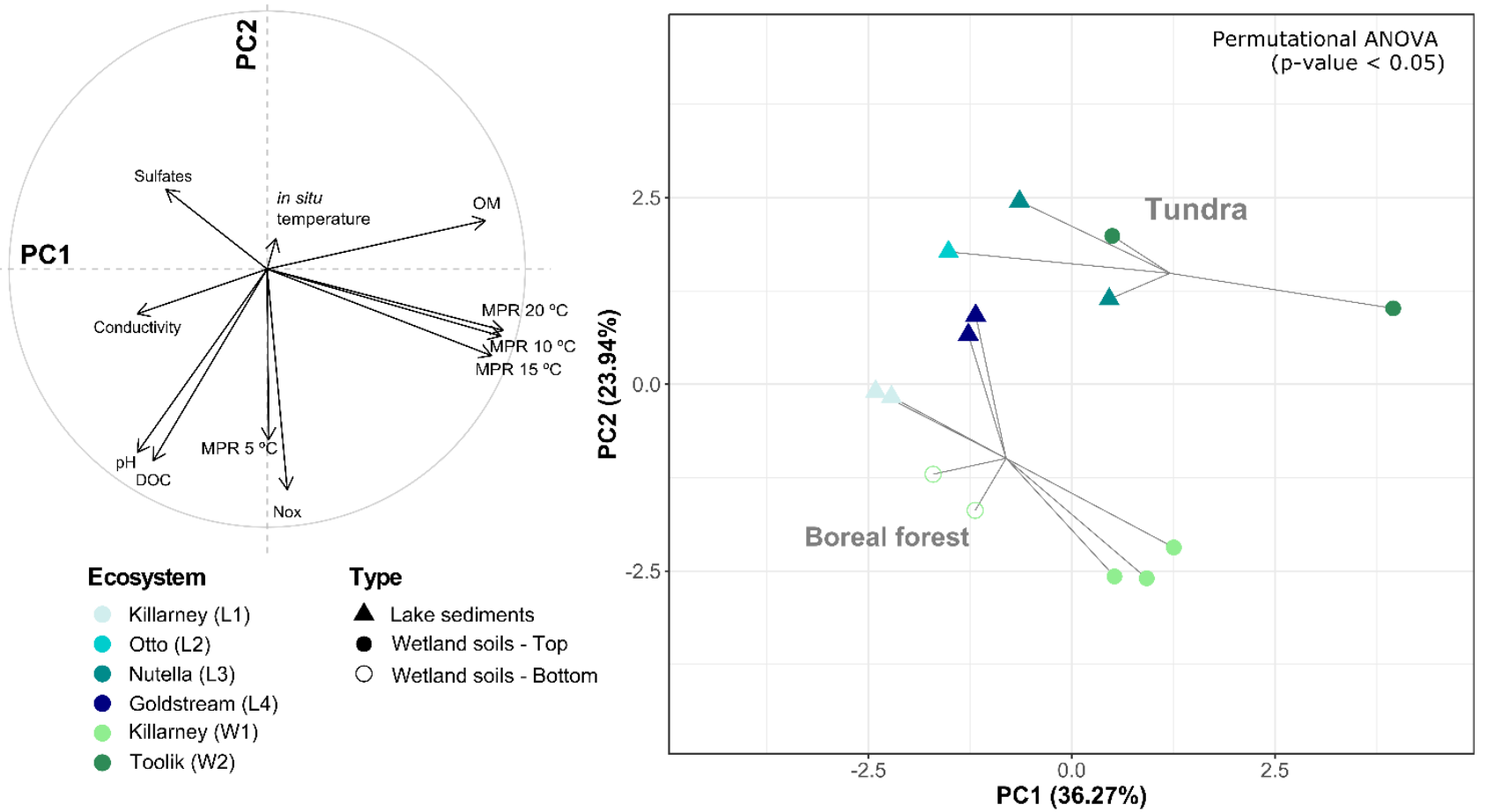

Figure 2. Principal component analysis (PCA) built from 11 variables showing the correlation between $\mathrm{CH}_{4}$ production rates (MPRs measured at 5, 10, 15 and $20{ }^{\circ} \mathrm{C}$ ) and in situ physicochemical data. Left panel (A) showed the correlation plot of variables and right panel (B) showed the site position on the ordination colored by ecosystem, while the symbol shape represents the different ecosystem types. Significant segregation by biome (PERMANOVA, F = 4.18, p-value $<0.05)$ was plotted as spiders (95\% confidence level). OM stands for organic matter and NOx for nitrates + nitrites. 


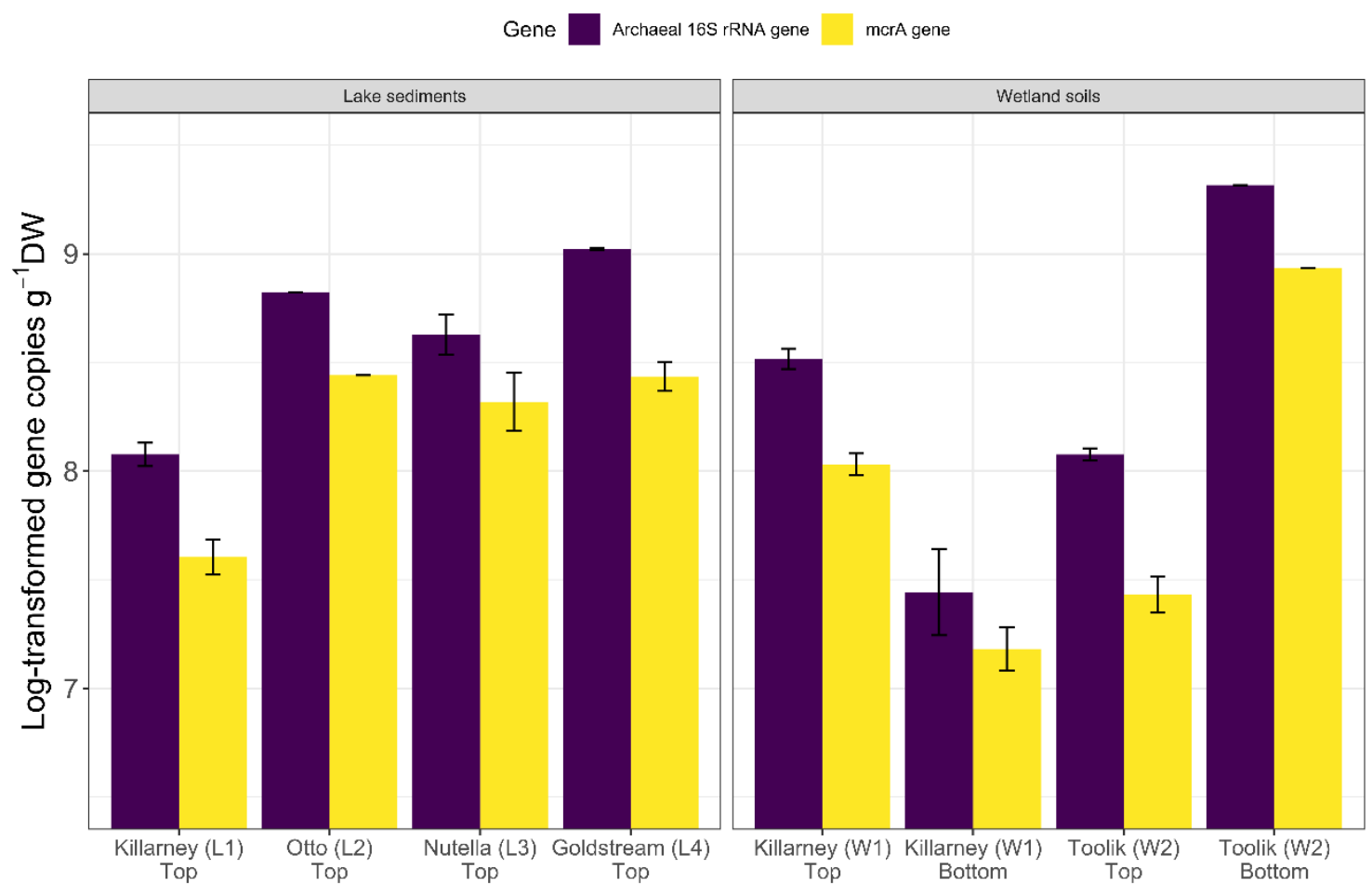

Figure 3. Abundance of $m c r A$ gene (in purple) and archaeal 16S rRNA gene (in yellow) quantified by qPCR from in situ lake sediment (L1-L4) and wetland soil (W1, W2, top and bottom). Error bars represented standard error between field replicates. 
bioRxiv preprint doi: https://doi.org/10.1101/2021.08.22.457279; this version posted August 23, 2021. The copyright holder for this preprint (which was not certified by peer review) is the author/funder, who has granted bioRxiv a license to display the preprint in perpetuity. It is made available under aCC-BY-ND 4.0 International license.

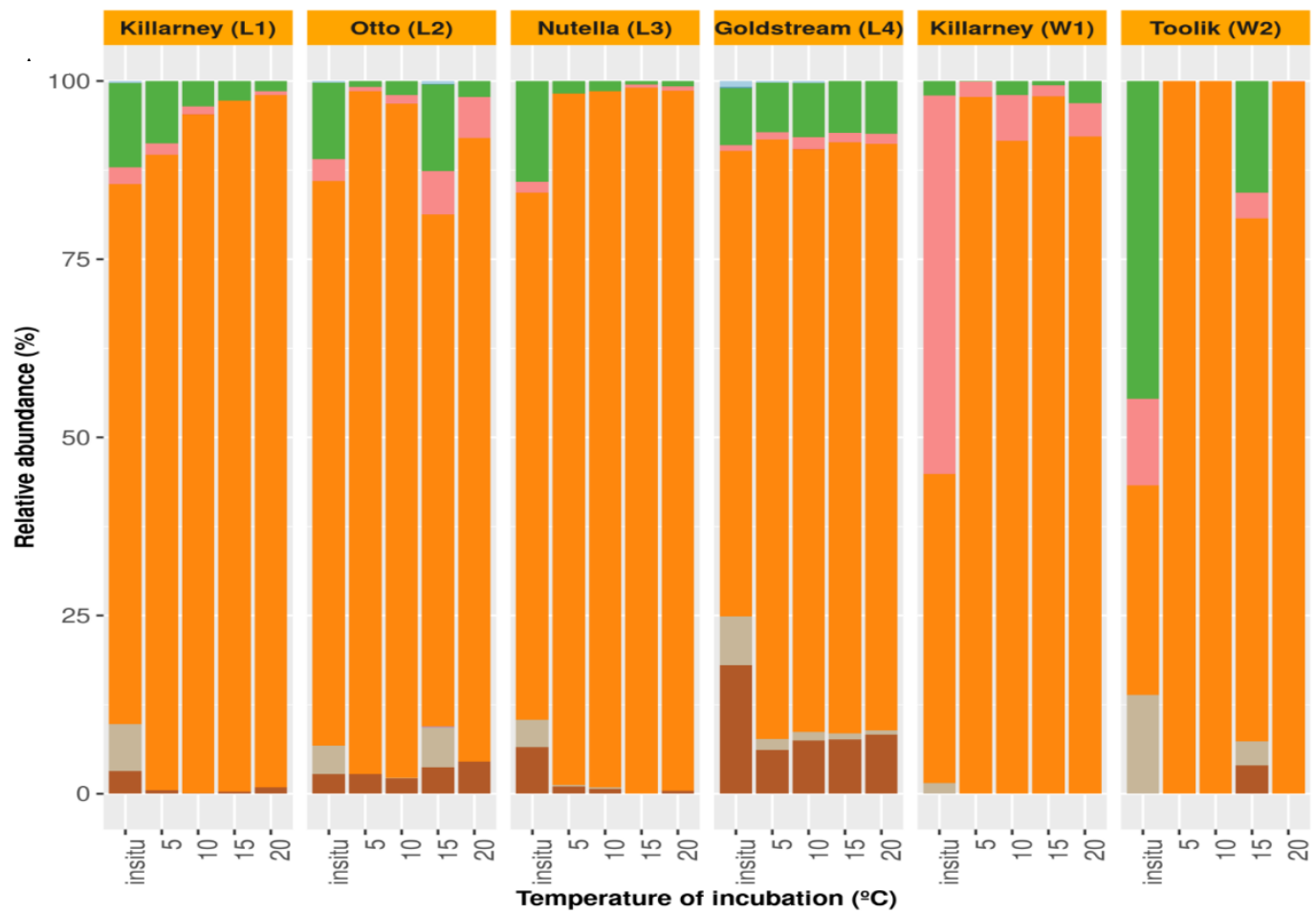

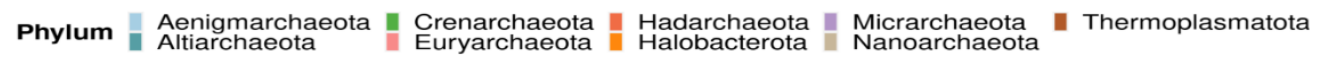

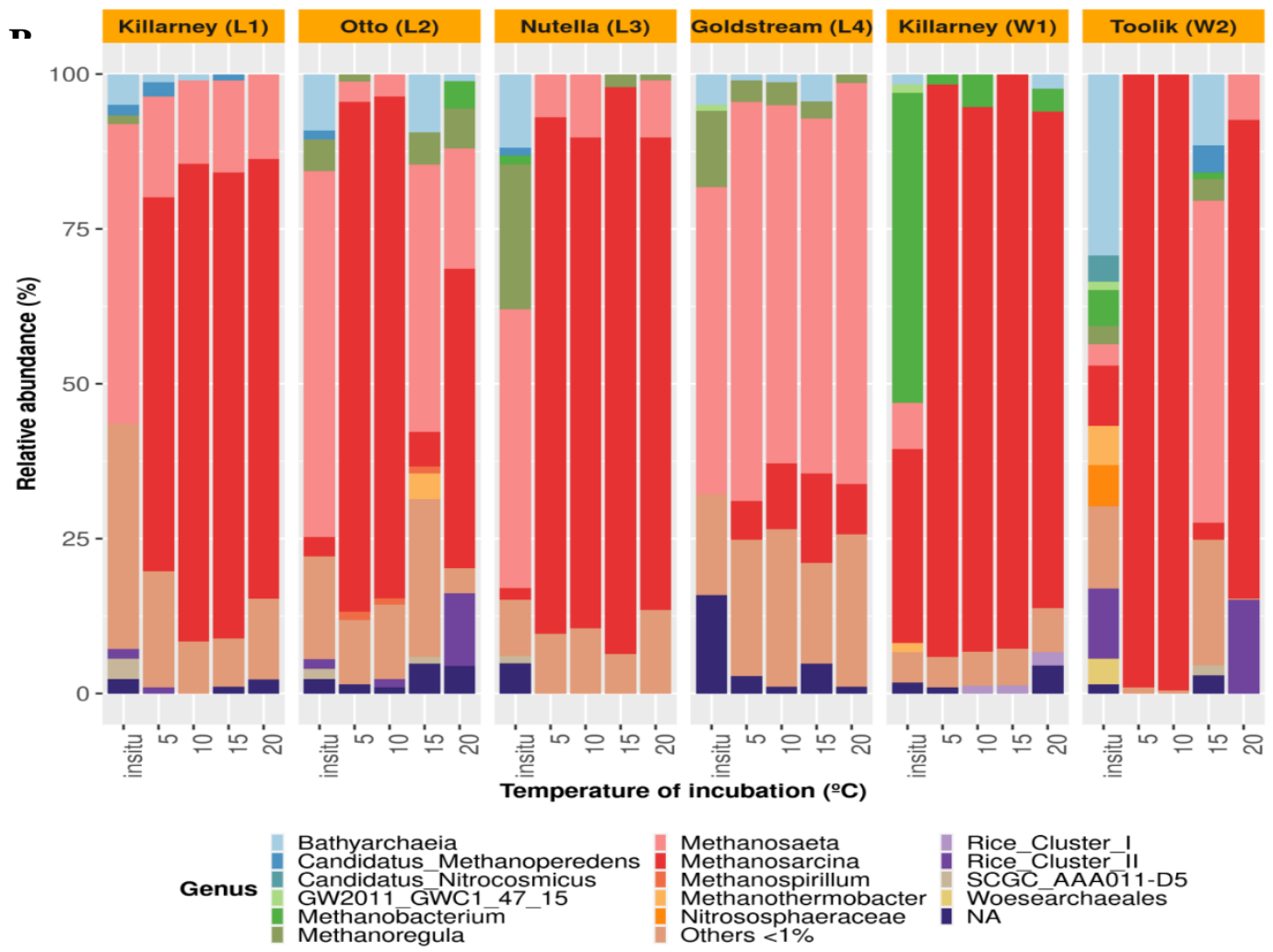


Figure 4. Taxonomic composition of the archaeal communities at the phylum (A) and genus (B) level, from in situ samples and after microcosm incubations at four temperatures, from four lake sediments and two wetland soils, according to 16S rRNA gene sequence analysis. Sequences with no taxonomic assignment (uncultured or unclassified) were grouped as NA. Other ASVs with less than $1 \%$ are indicated as "Others $<1 \%$ ) 

Table 1. Characteristics of studied ecosystems in Alaska, US.

\begin{tabular}{|c|c|c|c|c|c|}
\hline Ecosystem & Samples & Coordinates & Location & Biome & $\underset{(\mathbf{m})^{* *}}{\operatorname{Max} \text { Depth }}$ \\
\hline \multirow{4}{*}{ Lake sediments } & L1 & $64.869879 \mathrm{~N}, 147.901824 \mathrm{~W}$ & Killarney lake & $\begin{array}{c}\text { Boreal } \\
\text { forest }\end{array}$ & 2.1 \\
\hline & L2 & $63.846202 \mathrm{~N} 149.036019 \mathrm{~W}$ & Otto lake & \multirow{2}{*}{ Tundra } & 3.1 \\
\hline & L3 & $63.214548 \mathrm{~N}, 147.677642 \mathrm{~W}$ & Nutella lake $*$ & & 9.4 \\
\hline & $\mathrm{L} 4$ & $64.915801 \mathrm{~N}, 147.847705 \mathrm{~W}$ & Goldstream lake* & $\begin{array}{l}\text { Boreal } \\
\text { forest }\end{array}$ & 3.3 \\
\hline \multirow[t]{2}{*}{ Wetland soils } & W1 & $64.86975 \mathrm{~N}, 147.900616 \mathrm{~W}$ & Killarney lake & $\begin{array}{l}\text { Boreal } \\
\text { forest }\end{array}$ & - \\
\hline & W2 & $68.62497 \mathrm{~N}, 149.600381 \mathrm{~W}$ & Toolik lake & Tundra & 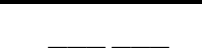 \\
\hline
\end{tabular}

* Informal lake names.

** Source: Sepulveda-Jauregui et al., 2015; Barret et al., 2019 (doi.org/10.15468/hhkhz2) 
Table 2 Physicochemical parameters measured in lake sediment and wetland soil samples. OM (organic matter), DOC (dissolved organic carbon), DW (dry weight). The values are mean of sampling points, (field duplicates) for lakes (L1, L3,L4) and three points for wetland soils (W1, W2; Ttop; B- bottom). \pm indicate standard deviation

\begin{tabular}{|c|c|c|c|c|c|c|c|c|c|}
\hline SAMPLES & $\begin{array}{l}\text { Depth } \\
\text { (cm) }\end{array}$ & $\begin{array}{c}\text { Temperature* } \\
\left({ }^{\circ} \mathbf{C}\right)\end{array}$ & $\mathbf{p H} * *$ & $\mathbf{O M} / \mathbf{F W}(\mathrm{g})$ & OM/DW (g) & DOC (mg.L $\left.L^{-1}\right)$ & $\begin{array}{l}\text { conductivity } \\
(\mathrm{mS} / \mathrm{cm})\end{array}$ & $\begin{array}{c}\text { Nitrate + } \\
\text { Nitrite }\left(\mathbf{N O}_{\mathbf{x}}\right) \\
\text { mg.L } \mathbf{L}^{-1} \\
\end{array}$ & $\begin{array}{c}\text { Sulfates }\left(\mathrm{SO}_{4}\right) \\
\text { mg.L } \\
-L^{-1}\end{array}$ \\
\hline Killarney (L1) & $0-10$ & $10.11 \pm 0.17$ & $7.07 \pm 0.01$ & $0.04 \pm 0.01$ & $0.09 \pm 0.01$ & $21.80 \pm 0.19$ & $1.73 \pm 0.02$ & $0.02 \pm 0.001$ & $2.18 \pm 0.52$ \\
\hline $\operatorname{Otto}(\mathbf{L} 2) * * *$ & $0-10$ & 13.92 & 6.92 & 0.03 & 0.140 & 3.00 & 1.130 & 0.02 & 12.36 \\
\hline Nutella (L3) & $0-10$ & $12.42 \pm 0.14$ & $6.14 \pm 0.17$ & $0.02 \pm 0.01$ & $0.17 \pm 0.11$ & $4.84 \pm 2.99$ & $0.47 \pm 0.29$ & $0.02 \pm 0.009$ & $0.07 \pm 0.01$ \\
\hline Goldstream (L4) & $0-10$ & $19.95 \pm 0.31$ & $6.8 \pm 0.09$ & $0.02 \pm 0.01$ & $0.17 \pm 0.07$ & $12.25 \pm 0.33$ & $1.59 \pm 0.49$ & $0.01 \pm 0.01$ & $4.17 \pm 3.71$ \\
\hline Killarney (W1 T) & $0-10$ & $9.04 \pm 2.39$ & $7.12 \pm 0.08$ & $0.08 \pm 0.02$ & $0.31 \pm 0.07$ & $16.92 \pm 5.15$ & $1.03 \pm 0.92$ & $1.33 \pm 0.04$ & $0.439 \pm 0.18$ \\
\hline Killarney (W1 B) & $10-20$ & $4.15 \pm 1.20$ & $7.23 \pm 0.01$ & 0.05 & 0.090 & $21.05 \pm 0.76$ & $0.32 \pm 0.36$ & $0.99 \pm 0.14$ & $0.370 \pm 0.09$ \\
\hline Toolik (W2 T) & $0-14$ & $8.7 \pm 0.28$ & $6.21 \pm 0.08$ & $0.09 \pm 1.56$ & $0.70 \pm 0.07$ & $5.65 \pm 2.19$ & $0.21 \pm 0.04$ & $0.25 \pm 0.007$ & ND \\
\hline Toolik (W2 B) & $14-20$ & 3.9 & 6.37 & 0.11 & 0.71 & 7.16 & 0.14 & 0.11 & ND \\
\hline
\end{tabular}

*measured in situ (at the location in the moment that the sample was taken)

**measured after extraction in water $(1: 4 \mathrm{w} / \mathrm{w})$

*** Otto Lake presented only one replicate 
Table 3: Average $\mathrm{Q}_{10}$ coefficient and energy activation (Ea) of methane production rate, observed for lakes sediment (L1-L4) and wetland soils (W1 and W2). Depth of wetland soils is indicated by T (top) and B (bottom).

\begin{tabular}{cccccc} 
& Location & $\left.\mathbf{Q}_{\mathbf{1 0}} \mathbf{( 5 - 1 5}^{\mathbf{0}} \mathbf{C}\right)$ & $\mathbf{Q}_{\mathbf{1 0}}\left(\mathbf{1 0 - 2 0}^{\mathbf{0}} \mathbf{C}\right)$ & $\mathbf{E a}\left(\mathbf{k J ~ m o l}^{-\mathbf{1}}\right)$ & $\mathbf{E a}(\mathbf{e V})$ \\
\hline \multirow{2}{*}{ LAKE } & Killarney (L1) & $5.1 \pm 0.02$ & $2.22 \pm 0.02$ & $85.3 \pm 3.1$ & $0.88 \pm 0.03$ \\
SEDIMENTS & Otto (L2) & 7.83 & 1.77 & 98.70 & 1.02 \\
& Nutella (L3) & $3.63 \pm 2.3$ & $2.26 \pm 0.4$ & $65.2 \pm 16.6$ & $0.67 \pm 0.1$ \\
& Goldstream (L4) & $6.44 \pm 3.8$ & $1.56 \pm 0.2$ & $78.3 \pm 25.9$ & $0.81 \pm 0.2$ \\
\hline \multirow{2}{*}{ WETLAND } & Killarney (W1 T) & $3.74 \pm 1.3$ & $1.7 \pm 0.2$ & $67.8 \pm 16.5$ & $0.70 \pm 0.1$ \\
SOILS & Killarney (W1 B) & $4.59 \pm 3.4$ & $1.75 \pm 1.2$ & $65.3 \pm 33.4$ & $0.67 \pm 0.3$ \\
& Toolik (W2 T) & $3.35 \pm$ & $2.56 \pm$ & $53.7 \pm 30.6$ & $0.55 \pm 0.3$ \\
& Toolik (W2 B) & ND & 1.76 & 38.50 & 0.39
\end{tabular}

*ND- Methanogenic activity was not detected at $5^{\circ} \mathrm{C}$. 